\title{
Nano-Magnesium Oxide: A Novel Bactericide Against Copper-Tolerant Xanthomonas perforans Causing Tomato Bacterial Spot
}

\author{
Y.-Y. Liao, A. L. Strayer-Scherer, J. White, A. Mukherjee, R. De La Torre-Roche, L. Ritchie, \\ J. Colee, G. E. Vallad, J. H. Freeman, J. B. Jones, ${ }^{\dagger}$ and M. L. Paret ${ }^{\dagger}$
}

First, second, tenth, and eleventh authors: Department of Plant Pathology, University of Florida, Gainesville, USA; first, second, sixth, ninth, and eleventh authors: North Florida Research and Education Center, University of Florida, Quincy, USA; third, fourth, and fifth authors: Department of Analytical Chemistry, The Connecticut Agricultural Experiment Station, New Haven, USA; seventh author: IFAS Statistics, University of Florida, Gainesville, USA; eighth author: Gulf Coast Research and Education Center, University of Florida, Wimauma. Accepted for publication 25 July 2018.

\begin{abstract}
Bacterial spot caused by Xanthomonas perforans causes significant damage on tomato in Florida. Due to the presence of copper $(\mathrm{Cu})$-tolerant $X$. perforans strains, $\mathrm{Cu}$ bactericides are not effective in disease management. Hence, there is a critical need to find alternatives for $\mathrm{Cu}$. Antibacterial activity of magnesium oxide (Nano- $\mathrm{MgO}$ ), and other metal oxide nanoparticles, were evaluated against a $\mathrm{Cu}$-tolerant and -sensitive $X$. perforans strain. In vitro experiments demonstrated high antibacterial activity of Nano-MgO against both strains compared with the commercial $\mathrm{Cu}$. The minimum inhibitory concentration of Nano- $\mathrm{MgO}$ is $25 \mu \mathrm{g} / \mathrm{ml}$ and the minimum bactericidal concentration is $100 \mu \mathrm{g} / \mathrm{ml}$ against a Cu-tolerant $X$. perforans strain after $4 \mathrm{~h}$ of exposure. Structural changes in the bacterial

membrane following exposure to Nano- $\mathrm{MgO}$ treatments compared with the controls were observed using transmission electron microscopy. In two greenhouse experiments with a $\mathrm{Cu}$-tolerant strain, bacterial spot severity was significantly reduced by Nano- $\mathrm{MgO}$ at $200 \mu \mathrm{g} / \mathrm{ml}$ compared with $\mathrm{Cu}-$ ethylene bis-dithiocarbamate (grower standard), and the untreated control $(P$ $=0.05$ ). In three field experiments, Nano- $\mathrm{MgO}$ at $200 \mu \mathrm{g} / \mathrm{ml}$ significantly reduced disease severity with no negative impact on yield compared with the untreated control. Inductively coupled plasma mass spectrometric analysis of the fruit confirmed that Nano-MgO application did not lead to the accumulation of $\mathrm{Mg}, \mathrm{Cu}, \mathrm{Ca}, \mathrm{K}, \mathrm{Mn}, \mathrm{P}$, and $\mathrm{S}$. This study is the first to demonstrate the potential of Nano-MgO against bacterial spot of tomato.
\end{abstract}

Tomato (Solanum lycopersicum) is an economically important specialty crop in the United States. In 2017, the total production was 12.5 million metric tons. The value of the crop totaled $\$ 1.67$ billion (USDA 2018). Florida, which accounted for $36 \%$ of the annual tomato production value (USDA 2018), is the largest fresh-market producer in the United States. Bacterial spot of tomato, caused by four Xanthomonas spp. (i.e., Xanthomonas euvesicatoria, X. gardneri, X. perforans, and X. vesicatoria) (Jones et al. 2004), is difficult to manage in Florida due to environmental conditions that favor the disease throughout the year. Although bacterial spot disease is a major bacterial disease in fresh-market tomato production, leading to as much as $50 \%$ yield losses and reduced fruit quality (Vallad et al. 2010), there are only a few treatment options available for effective disease management.

In the 1950s, the antibiotic streptomycin was used extensively for field management of bacterial spot on tomato. Shortly thereafter, streptomycin-resistant Xanthomonas strains became common in the field (Stall and Thayer 1962; Thayer and Stall 1961). After the discovery of streptomycin-resistant xanthomonads, growers began to rely heavily on copper $(\mathrm{Cu})$ bactericides. Continuous use of $\mathrm{Cu}$ bactericides over many decades has provided high selection pressure, which favors $\mathrm{Cu}$-tolerant strains. As a result, $\mathrm{Cu}$ tolerant strains were detected as early as the 1960s and were later characterized in 1983 (Cooksey et al. 1990; Marco and Stall 1983).

†Corresponding authors: M. L. Paret; E-mail: paret@ufl.edu; and J. B. Jones; E-mail: jbjones@ufl.edu

Funding: This research was conducted with funding from the University of Florida Research grants for M. L. Paret, United States Department of Agriculture-Current Research and Information System (USDA-CRIS) project HATCH FLA-NFC005242, and USDA NIFA AFRI award 2016-67021-24985 to J. White.

(c) 2019 The American Phytopathological Society
With the presence of $\mathrm{Cu}$-tolerant strains, growers moved to applying combinations of $\mathrm{Cu}$ and mancozeb, an ethylene-bis-dithiocarbamate (EBDC) fungicide, to reduce foliar bacterial populations. However, $\mathrm{Cu}$-EBDC combinations could not effectively manage $\mathrm{Cu}$-tolerant strains when environmental conditions favored the disease (Jones and Jones 1985).

Given the limited availability of effective disease management options, $\mathrm{Cu}$ bactericides have continued to be frequently used by growers (Marco and Stall 1983; Ritchie and Dittapongpitch 1991; Vallad et al. 2010). The heavy use of $\mathrm{Cu}$ bactericides might lead to metal accumulation in the soil (Pietrzak and McPhail 2004). Considering the negative aspects of $\mathrm{Cu}$ use and accumulation, identifying sustainable and effective alternative management strategies is critical. Other currently available treatment options have significant limitations as well; a commercial plant defense activator can reduce yield (Obradovic et al. 2005) and the efficacy of bacteriophages is adversely affected by low humidity, UV light, and high temperature (Jones et al. 2012; Obradovic et al. 2004). Florida tomato growers continue to use a combination of $\mathrm{Cu}$ bactericides, plant defense activators, biofungicides, and cultural practices, including use of healthy seed and transplants (Potnis et al. 2015).

Recently, nanomaterials have been the focus of a number of studies for management of plant diseases (Servin et al. 2015). Bacterial spot of tomato has been one of the targeted diseases for studies on the use of nanomaterials for disease control due to the limitations of $\mathrm{Cu}$ bactericides and other management options. In one study, three different photocatalytic crystalline nanoscale titanium dioxide $\left(\mathrm{Nano}-\mathrm{TiO}_{2}\right)$ compounds were compared for disease control (Paret et al. 2013). One of the $\mathrm{TiO}_{2}$ nanomaterials, nanoscale $\mathrm{TiO}_{2}$ doped (incorporation of other materials into the structure of $\mathrm{Nano}^{-\mathrm{TiO}_{2}}$ ) with zinc $\left(\mathrm{TiO}_{2} / \mathrm{Zn}\right)$ (Averett and Averett 2015) at approximately 500 to $800 \mu \mathrm{g} / \mathrm{ml}$ showed greater ability to control bacterial spot in the field in comparison with the grower 
standard, Cu-EBDC (Paret et al. 2013). However, $\mathrm{TiO}_{2} / \mathrm{Zn}$ had no antibacterial effect without light exposure, and tomato plants exhibited phytotoxicity following the sixth application at approximately $500 \mu \mathrm{g} / \mathrm{ml}$ in field trials in Florida (Paret et al. 2013). Another hybrid nanomaterial that was recently designed and assessed for controlling bacterial spot on tomato transplants is AgdsDNA-graphene oxide (GO), a material which has minimal aggregation properties, unlike commercial silver $(\mathrm{Ag})$ nanoparticles, as a result of being formulated with GO and double-stranded (ds)DNA (Ocsoy et al. 2013a,b). This nanomaterial was effective in reducing disease severity when applied at a concentration of $100 \mu \mathrm{g} / \mathrm{ml}$, which is equivalent to $\mathrm{Ag}$ at approximately $16 \mu \mathrm{g} / \mathrm{ml}$ (Strayer et al. 2016). In comparison, $\mathrm{Cu}$ routinely sprayed on tomato in transplant houses or in the field to control bacterial spot may reach approximately $540 \mu \mathrm{g} / \mathrm{ml}$. Although Ag-dsDNA-GO may be a potential alternative to $\mathrm{Cu}$, the material is currently unavailable in large quantities and is costly. Additionally, after treatment, the fate of Ag-dsDNA-GO in the environment needs to be evaluated, including Ag accumulation in the soil and fruit.

Another nanomaterial of interest as a new bactericide is magnesium oxide nanoparticles (Nano-MgO). In the past decade, micron-sized and nano-sized $\mathrm{MgO}$ particles were shown to have antibacterial activity against several mammalian pathogens (Aruoja et al. 2009; Huang et al. 2005; Sawai 2003). Sawai (2003) treated mammalian pathogens Staphylococcus aureus and Escherichia coli with micron-sized $\mathrm{MgO}$ powder (3.7 $\mu \mathrm{m}$ in sterile saline) and quantitatively evaluated the change in electrical conductivity as a measurement of bacterial metabolism. Antibacterial activity was observed after $15 \mathrm{~h}$ of exposure to micron-sized $\mathrm{MgO}$ concentrations as low as $0.2 \mu \mathrm{g} / \mathrm{ml}$. In that study, generation of oxygen radicals was suggested as one of the possibilities for antibacterial activity (Sawai et al. 2000). For plant pathogens, high inhibition rates in germination of fungal spores of Alternaria alternata, Fusarium oxysporum, Rhizopus stolonifer, and Mucor plumbeus upon exposure to Nano-MgO (approximately $50 \pm 10 \mathrm{~nm}$ ) at concentrations as low as $100 \mathrm{mg} /$ liter were reported (Wani and Shah 2012). In that study, the authors suggested that nanoparticles may inhibit the release of extracellular enzymes and metabolites that are essential for fungal survival against toxins or environmental changes (Pérez-de-Luque and Rubiales 2009). It was also observed that nanoparticles suppress enzymes and toxins used for pathogenicity by the fungal pathogens (Bhainsa and D'Souza 2006; Vahabi et al. 2011).

Huang et al. (2005) evaluated the possible mechanism of Nano$\mathrm{MgO}$ antibacterial activity and observed that activity against Bacillus subtilis var. niger spores and S. aureus cells increased with decreasing particle size. For particles in the size range of 45 to $70 \mathrm{~nm}$, the bactericidal efficacy of Nano- $\mathrm{MgO}$ increased slowly with decreasing particle size. A strong improvement of bactericidal efficacy was observed below $45 \mathrm{~nm}$. To compare with $\mathrm{Nano}^{-\mathrm{TiO}_{2}}$ (29 nm, light activated), Nano- $\mathrm{MgO}$ at $26 \mathrm{~nm}$ showed similar bactericidal activity against $S$. aureus and much higher bactericidal efficiency against $B$. subtilis without light activation. Huang et al. (2005) also confirmed that the mechanism of bactericidal activity of Nano-MgO is the release of high concentrations of highly reactive superoxide ions generated on the surface of the Nano-MgO particles. Those reactive oxygen species can break the peptide linkages in the bacterial cell wall or endospores (Huang et al. 2005). Because other metal oxide nanoparticles, including $\mathrm{Cu}(\mathrm{I})$ oxide $\left(\mathrm{Nano}^{-} \mathrm{Cu}_{2} \mathrm{O}\right)$, zinc oxide (Nano- $\mathrm{ZnO}$ ), manganese oxide $\left(\mathrm{Nano}-\mathrm{Mn}_{2} \mathrm{O}_{3}\right.$ ), and iron oxide (Nano- $\mathrm{Fe}_{2} \mathrm{O}_{3}$ ), showed bactericidal activity in other studies (Azam et al. 2012; Hoseinzadeh et al. 2017; Servin et al. 2015), we examined the antibacterial potentials of these metallic oxide nanoparticles along with Nano-MgO.

The goal of this study was to evaluate novel disease management strategies for bacterial spot of tomato. We hypothesized that the nanoparticle $\mathrm{MgO}$ and other metal oxides will have greater antibacterial properties compared with commercial micron-size
$\mathrm{Cu}$ and provide more effective control of bacterial spot of tomato. The objectives of this study were to (i) evaluate the in vitro antibacterial activity of metal oxide nanoparticles against $\mathrm{Cu}$-tolerant $X$. perforans, (ii) assess the ability of nanoparticles to reduce bacterial spot severity under greenhouse and field conditions, (iii) study potential phytotoxic effects of the metallic oxide nanoparticles on tomato, and (iv) evaluate whether application of metal oxide nanoparticles on tomato results in the increased accumulation of elements in fresh tomato fruit.

\section{MATERIALS AND METHODS}

Bacterial strains and storage. Two $X$. perforans strains, GEV485 (Cu-tolerant) and 91-118 (Cu-sensitive), were isolated from tomato in Florida and used in this study. Bacterial cells from pure cultures of these strains were suspended in sterile $30 \%$ glycerol solution and stored at $-80^{\circ} \mathrm{C}$. For each experiment, bacteria were streaked from the glycerol stock onto nutrient agar (NA) medium (BBL, Becton Dickinson and Co., Cockeysville, $\mathrm{MD}$ ), incubated at $28^{\circ} \mathrm{C}$, and transferred every 24 to $48 \mathrm{~h}$ until used for streaking on NA plates for inoculum. Bacterial cells were collected from cultures grown on NA for $24 \mathrm{~h}$ and suspended in $0.01 \mathrm{M} \mathrm{MgSO}_{4}$, and the suspensions were adjusted to absorbance at $600 \mathrm{~nm}=0.3$ (approximately $5 \times 10^{8} \mathrm{CFU} / \mathrm{ml}$ ). The final concentrations of bacterial suspensions were adjusted to $10^{8}$ $\mathrm{CFU} / \mathrm{ml}$.

Metal oxide nanoparticles. Ag nanoparticles (Nano-Ag) (Ag, 99.99\%, $20 \mathrm{~nm}$, metal basis), $\mathrm{Cu}(\mathrm{I})$ oxide nanoparticles (Nano- $\left.\mathrm{Cu}_{2} \mathrm{O}\right)\left(\mathrm{Cu}_{2} \mathrm{O}, 18 \mathrm{~nm}\right.$, super fine 99.86\%), $\mathrm{Zn}$ oxide nanoparticles (Nano-ZnO) ( $\mathrm{ZnO}, 99+\%, 10$ to $30 \mathrm{~nm})$, Nano$\mathrm{MgO}(\mathrm{MgO}, 99+\%, 20 \mathrm{~nm}$ ), Mn oxide nanoparticles (Nano$\left.\mathrm{Mn}_{2} \mathrm{O}_{3}\right)\left(\mathrm{Mn}_{2} \mathrm{O} 3,99.2 \%, 30 \mathrm{~nm}\right)$, and $\mathrm{Fe}$ oxide nanoparticles $\left(\mathrm{Nano}-\mathrm{Fe}_{2} \mathrm{O}_{3}\right)\left(\mathrm{Fe}_{2} \mathrm{O}_{3}, \gamma, 99 \%, 20\right.$ to $\left.40 \mathrm{~nm}\right)$ were purchased in powder form from U.S. Research Nanomaterials, Inc. (Houston, TX). Each nanoparticle was suspended and sonicated in autoclaved deionized water, adjusted to $10,000 \mu \mathrm{g} / \mathrm{ml}$, and used as a stock suspension.

In vitro assays. In order to select effective nanoparticles for controlling bacterial spot disease of tomato, several metallic oxide nanoparticles and Nano-Ag were compared with Kocide 3000 (a micron-sized commercial $\mathrm{Cu}$ bactericide and fungicide; DuPont, Wilmington, DE) for antibacterial activity against the Cu-tolerant strain GEV485 and Cu-sensitive strain 91-118. Nano-Ag is an antibacterial material (Lok et al. 2007; Marambio-Jones and Hoek 2010; Pal et al. 2007) and is the active ingredient in the formulated silver-based nanoparticle Ag-dsDNA-GO (Strayer et al. 2016); hence, it was used in this experiment as a comparison with other metal oxide nanoparticles. The bacterial cells were grown on NA plates for $24 \mathrm{~h}$ at $28^{\circ} \mathrm{C}$ and bacterial cells were then transferred to NA plates containing $\mathrm{Cu}$ at $20 \mu \mathrm{g} / \mathrm{ml}$; that is, $\mathrm{Cu}$ (II) sulfate pentahydrate $\left(\mathrm{CuSO}_{4} \cdot 5 \mathrm{H}_{2} \mathrm{O}\right)$ (Sigma-Aldrich, St. Louis), and incubated for $24 \mathrm{~h}$ at $28^{\circ} \mathrm{C}$. Bacterial cells were collected from NA plates and suspended in sterile $0.01 \mathrm{M}$ solution of $\mathrm{MgSO}_{4}(2.46 \mathrm{~g} / \mathrm{liter})$ in deionized water. Suspensions were diluted to $10^{5} \mathrm{CFU} / \mathrm{ml}$ and $20 \mu \mathrm{l}$ of the bacterial suspension was transferred to $2 \mathrm{ml}$ of each treatment in a sterile glass tube: Nano-Ag, Nano- $\mathrm{Cu}_{2} \mathrm{O}$, Nano-ZnO, Nano$\mathrm{Fe}_{2} \mathrm{O}_{3}$, Nano-MgO, Nano- $\mathrm{Mn}_{2} \mathrm{O}_{3}$, and the $\mathrm{Cu}$ bactericide, Kocide 3000 (DuPont), were prepared at 100 and $1,000 \mu \mathrm{g} / \mathrm{ml}$. Kocide 3000 contains $30 \%$ metallic $\mathrm{Cu}$ in the form of copper hydroxide $\mathrm{Cu}$ $\left.(\mathrm{OH})_{2}\right)$. Kocide 3000 at $1 \mathrm{~g} /$ liter contains $\mathrm{Cu}$ at approximately $300 \mu \mathrm{g} / \mathrm{ml}$. Each treatment consisted of three replications for each bacterial strain. For the control group, the glass tube only contained $2 \mathrm{ml}$ of sterile tap water and $20 \mu \mathrm{l}$ of the bacterial working suspension. The tubes were incubated at $28^{\circ} \mathrm{C}$ on an orbital shaker (150 rpm). At 1 , 4, and $24 \mathrm{~h}, 50 \mu \mathrm{l}$ was sampled from each tube and plated on NA. NA plates were incubated at $28^{\circ} \mathrm{C}$ for $48 \mathrm{~h}$. Bacterial colonies were counted on each plate and converted to $\mathrm{CFU} / \mathrm{ml}$. The in vitro assay was repeated twice. 
Determination of minimum inhibitory concentrations and minimum bactericidal concentrations. To further understand the bactericidal ability of Nano-MgO, minimum inhibitory concentrations (MIC) and minimum bactericidal concentrations (MBC) were determined using the in vitro assays described above. MIC was defined as the lowest concentration with significant decrease in pathogen viability, $\mathrm{MBC}$ was defined as the lowest concentration at which $99.9 \%$ or more of the pathogen is killed (Cosentino et al. 1999). As previously described, Cu-tolerant strain GEV485 suspensions were diluted to $10^{5} \mathrm{CFU} / \mathrm{ml}$ and $20 \mu \mathrm{l}$ of the bacterial suspension were transferred to tubes containing 2-ml suspensions of Nano-MgO at $12.5,25,50$, or $100 \mu \mathrm{g} / \mathrm{ml}$. Each treatment consisted of three replications for each bacterial strain. For the control, the glass tube only contained $2 \mathrm{ml}$ of sterile tap water and $20 \mu \mathrm{l}$ of the bacterial working suspension. The tubes were incubated at $28^{\circ} \mathrm{C}$ on an orbital shaker $(150 \mathrm{rpm})$. After $4 \mathrm{~h}, 50 \mu \mathrm{l}$ were sampled from each tube and plated on NA. Bacterial colonies were counted on each plate and converted to $\mathrm{CFU} / \mathrm{ml}$. The in vitro assay was repeated once.

Transmission electron microscopy. An in vitro assay was used for treating $X$. perforans cells with Nano-MgO or the $\mathrm{Cu}$ bactericide, Kocide 3000 (DuPont), for morphological analysis of the bacterial cells using transmission electron microscopy (TEM). Bacterial suspension ( $1 \mathrm{ml}$ of $10^{8} \mathrm{CFU} / \mathrm{ml}$ ) of $\mathrm{Cu}$-tolerant strain GEV485 was transferred to $1 \mathrm{ml}$ of Nano-MgO at $100 \mu \mathrm{g} / \mathrm{ml}$ or Kocide 3000 at $100 \mu \mathrm{g} / \mathrm{ml}$. For the control, the glass tube only contained $1 \mathrm{ml}$ of sterile tap water and $1 \mathrm{ml}$ of the bacterial suspension. The glass tubes were incubated for $4 \mathrm{~h}$ at $28^{\circ} \mathrm{C}$. Untreated controls were incubated for the same duration. One drop of $2 \%$ paraformaldehyde-fixed Nano-MgO, Kocide 3000-treated, and untreated $X$. perforans cell suspensions were trapped on carboncoated copper grids and allowed to dry. The cells were negatively stained by $2 \%$ uranyl acetate for $30 \mathrm{~s}$, and the excess was removed with filter paper. The samples were washed with one drop of sterile deionized $\mathrm{H}_{2} \mathrm{O}$. The cells were observed using FEI Spirit TEM, 120 kV (FEI Company, Hillsboro, OR).

Greenhouse experiments. Nano- $\mathrm{Cu}_{2} \mathrm{O}$, Nano- $\mathrm{ZnO}$, and Nano-MgO, which showed greater antibacterial activity than the other compounds in the in vitro assays, were selected for further testing in the greenhouse experiments. The following suspensions ( $200 \mathrm{ml}$ each) were prepared in sterile tap water: Nano- $\mathrm{Cu}_{2} \mathrm{O}$, Nano$\mathrm{ZnO}$, and Nano-MgO at 100, 200, 500, and 1,000 $\mathrm{\mu g} / \mathrm{ml}$; or a combination of Kocide 3000 (2.1 g/liter) and Penncozeb 75DF (CuEBDC, 1.2 g/liter; United Phosphorus, Inc., King of Prussia, PA). Sterile tap water served as the control. Approximately $30 \mathrm{ml}$ of the material was sprayed on the foliage of 3- to 4-week-old Bonny Best tomato plants. The leaf surfaces receiving the spray materials were allowed to air dry before spraying the leaf surfaces with a suspension of the Cu-tolerant $X$. perforans strain, GEV485, adjusted to $5 \times 10^{8} \mathrm{CFU} / \mathrm{ml}$. The inoculated plants were then placed in plastic bags that were tightened around the base of the pot with a rubber band and placed in a growth chamber at $28^{\circ} \mathrm{C}$. After 48 $\mathrm{h}$, the bags were removed and the plants transferred to the greenhouse. The plants were assessed for disease severity and phytotoxicity using the Horsfall-Barratt disease severity scale (Barratt and Horsfall 1945) by rating every other day beginning at 2 days postinoculation, with the last rating at 14 days postinoculation. The disease rating assessed the overall affected area based on symptoms that included lesions, foliar blighting, and discoloration. The area under the disease progress curve (AUDPC) was then calculated using the midpoint values (Campbell and Madden 1990). There were four replications per treatment and the experiment was repeated twice.

Field experiments. Based on performance in greenhouse experiments, Nano- $\mathrm{Cu}_{2} \mathrm{O}$ and $\mathrm{Nano}-\mathrm{MgO}$ were selected for field testing against bacterial spot disease of tomato in three trials (4 August to 11 September 2015, Quincy, FL; 18 April to 13 June 2016, Quincy, FL; and 31 March to 26 May 2016, Wimauma, FL).
Each treatment had four replications consisting of 15 BHN 602 tomato plants in Quincy and HM1823 in Wimauma. The plots were arranged in a completely randomized block design. In Quincy, bed dimensions were $20.3 \mathrm{~cm}$ tall and $76.2 \mathrm{~cm}$ wide. Beds were spaced $1.8 \mathrm{~m}$ apart and plants were spaced $50.8 \mathrm{~cm}$ within the row (McAvoy et al. 2012). In Wimauma, beds were spaced $1.5 \mathrm{~m}$ apart and plants were spaced $60.96 \mathrm{~cm}$ within the row. Fertilizers were applied to plots based on soil type and cooperative extension recommendations (Freeman et al. 2014). Tomato transplants were grown in the greenhouse in 128-cell containers before transplant. After transplanting, the treatments were sprayed on foliar parts of the tomato plant at the rate of 1.2 liters for four plots 1 week prior to bacterial inoculation. The treatments consisted of $\mathrm{Nano}-\mathrm{Cu}_{2} \mathrm{O}$ or Nano-MgO sonicated suspension at 200 and $1,000 \mu \mathrm{g} / \mathrm{ml}$ with constant shaking while applying, Kocide 3000 (2.1 g/liter), the grower standard Kocide 3000 (2.1 g/liter) in combination with Penncozeb 75DF (Cu-EBDC, $1.2 \mathrm{~g} /$ liter), and an untreated control. To insure adequate disease development in the field plots, a suspension of $\mathrm{Cu}$-tolerant $X$. perforans strain GEV485 bacterial strain adjusted to $5 \times 10^{8} \mathrm{CFU} / \mathrm{ml}$ in deionized water was applied to the foliage in the field by spraying the $1 \mathrm{st}, 8$ th, and 15 th plant in each plot. One liter of each antibacterial treatment was applied to each plot weekly with $\mathrm{CO}_{2}$ tanks and a u-shaped sprayer until 1 week before fruit harvesting. The plants were assessed for disease severity and phytotoxicity using the Horsfall-Barratt disease severity scale (Barratt and Horsfall 1945) every week after inoculation until harvest. The AUDPC was then calculated as above (Campbell and Madden 1990). There were four replications per treatment and the experiment was done three times. In all, 12 of 15 plants, excluding the 2 toward the two ends of plots, were harvested for assessing the yield. The fruit were harvested at green/early breaker stage and then graded by United States Department of Agriculture (USDA) standards. At least two harvests were made for each field experiment, which is common for fresh-market tomato production in Florida.

Elemental analysis of the fruit. At harvest, five mediumsized mature-green stage fruit, with diameters between 5.72 and $6.43 \mathrm{~cm}$ according to the USDA standards (Kelley et al. 2010; USDA 1997) were collected from each of the treatments. The fruit were harvested from outside of the canopy from the first and the last plants of each of four plots from the 2015 fall Quincy trial. Handwashed fruit were collected twice for analysis at 7 and 20 days after final application. In total, 4 to $8 \mathrm{~g}$ of fresh tomato fruit with peel and flesh and 4 to $8 \mathrm{~g}$ of peel-only and flesh-only samples were dried in an electric oven at $70^{\circ} \mathrm{C}$ for $48 \mathrm{~h}$. Dried samples were predigested overnight with $2 \mathrm{ml}$ of concentrated nitric acid and $2 \mathrm{ml}$ of $\mathrm{H}_{2} \mathrm{O}_{2}$. After the predigestion step, these samples were digested at $115^{\circ} \mathrm{C}$ for $45 \mathrm{~min}$, then cooled to room temperature. The samples were filtered through cotton plugs and the volume was adjusted to $50 \mathrm{ml}$. The samples were stored at room temperature until analysis. Al, B, $\mathrm{Ca}, \mathrm{Cu}, \mathrm{Fe}, \mathrm{K}, \mathrm{Mg}, \mathrm{Mn}, \mathrm{Mo}, \mathrm{Na}, \mathrm{P}, \mathrm{S}$, and $\mathrm{Zn}$ concentrations were determined by inductively coupled plasma optical emission spectroscopy (Thermo-Jarrell Ash, Franklin, MA). Multielemental standard solution ( $100 \mathrm{mg} /$ liter) was obtained from SPEX CertiPred (Metuchen, NJ). Analysis was performed following the methods described in previous studies (Mattina et al. 2003; Musante and White 2012; Stilwell and Graetz 2001). The digests were quantified against a four-point calibration curve that had been previously evaluated for linearity and accuracy. Analytical blanks, matrix blanks, and calibration verification samples were included in each sequence.

Statistical analysis. The data collected from the in vitro assays and greenhouse and field experiments were evaluated for statistical significance using analysis of variance followed by pairwise comparisons using either the least significant difference or the Student-Newman-Keuls method in IBM SPSS Statistics, version 22. A $P$ value of 0.05 was used to evaluate significance. 


\section{RESULTS}

Effect of metallic oxide nanoparticles on in vitro growth of $X$. perforans. Nano- $\mathrm{Ag}$, Nano- $\mathrm{ZnO}$, and $\mathrm{Nano}-\mathrm{MgO}$ had significant antimicrobial activity at all concentrations against the $\mathrm{Cu}$-tolerant strain, X. perforans GEV485 (Fig. 1). Both concentrations of Nano-Ag $(1,000$ and $100 \mu \mathrm{g} / \mathrm{ml})$ and Nano-ZnO at 1,000 $\mu \mathrm{g} / \mathrm{ml}$ completely inhibited bacterial growth (100\% reduction) within $1 \mathrm{~h}$ (Fig. 1A). Both Nano-MgO and Nano-ZnO at $100 \mu \mathrm{g} / \mathrm{ml}$ reduced bacterial populations at $1 \mathrm{~h}$ (approximately $70 \%$ reduction for Nano- $\mathrm{ZnO}$ and approximately $20 \%$ reduction for Nano-MgO) and $4 \mathrm{~h}$ (100\% reduction) (Fig. 1A and $\mathrm{B})$ compared with the untreated control. Nano- $\mathrm{Cu}_{2} \mathrm{O}$ at $1,000 \mu \mathrm{g} / \mathrm{ml}$ inhibited bacterial growth within $24 \mathrm{~h}(100 \%$ reduction) (Fig. 1C). In contrast, the $\mathrm{Cu}$

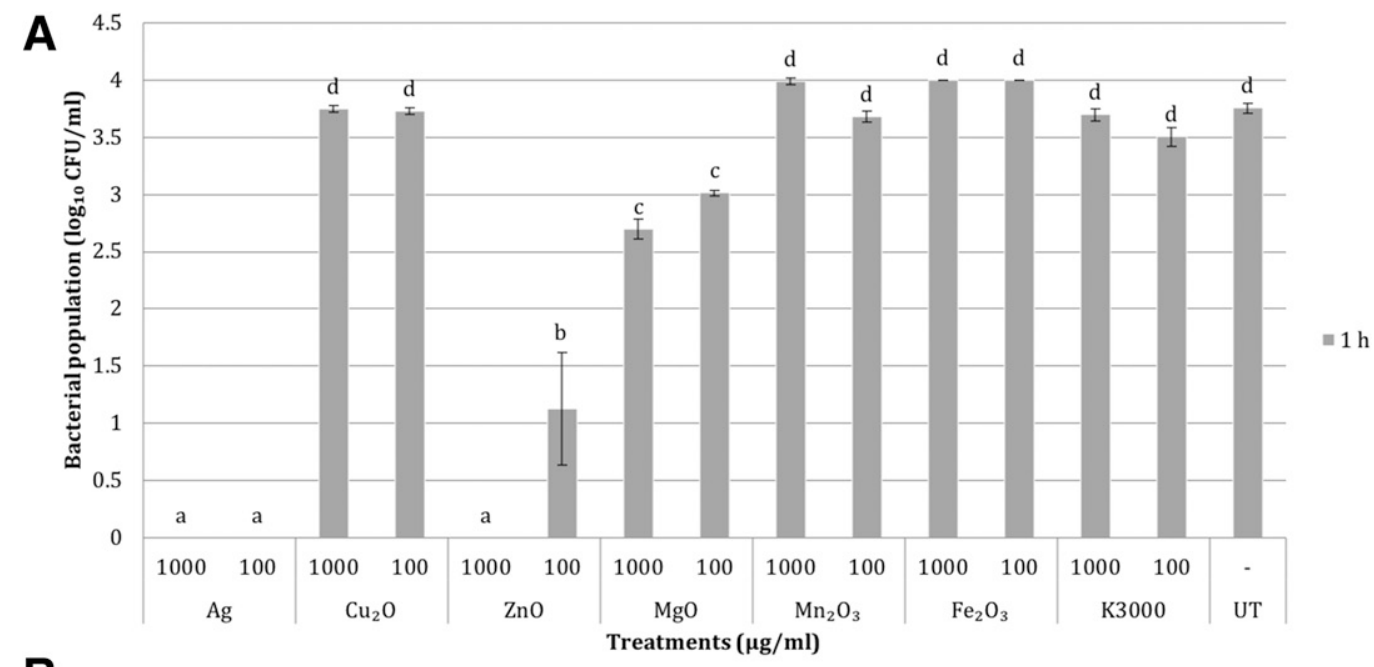

B

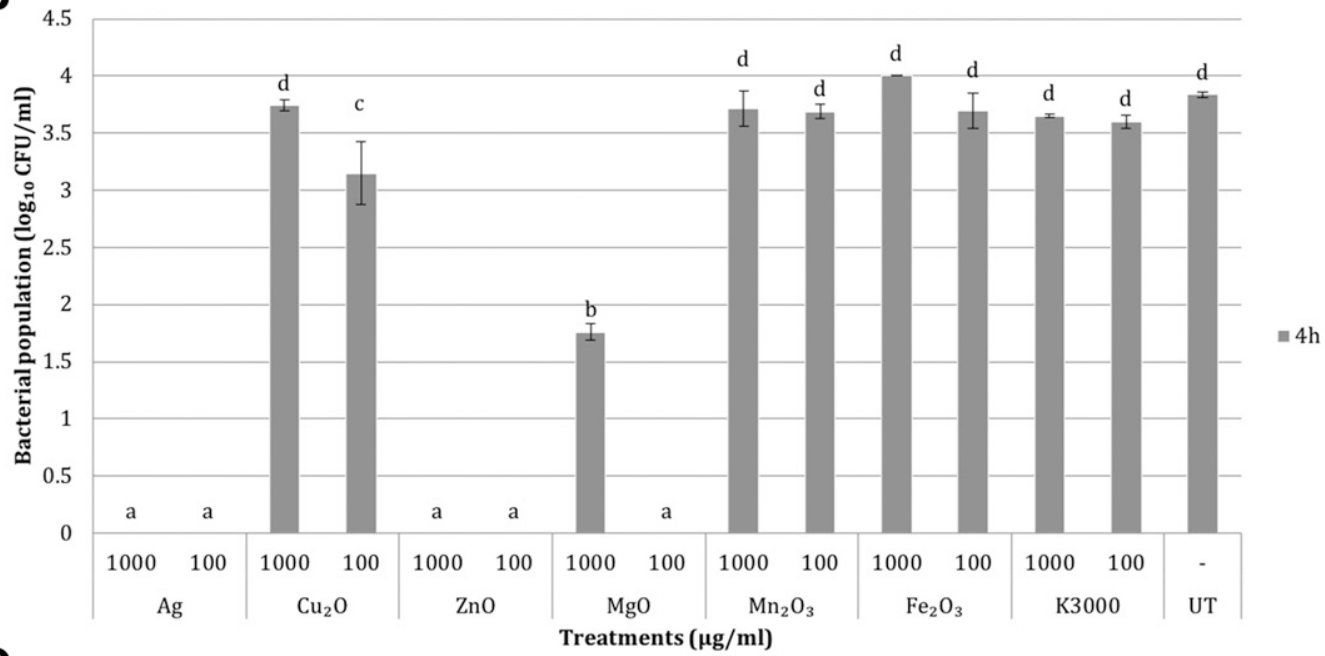

C

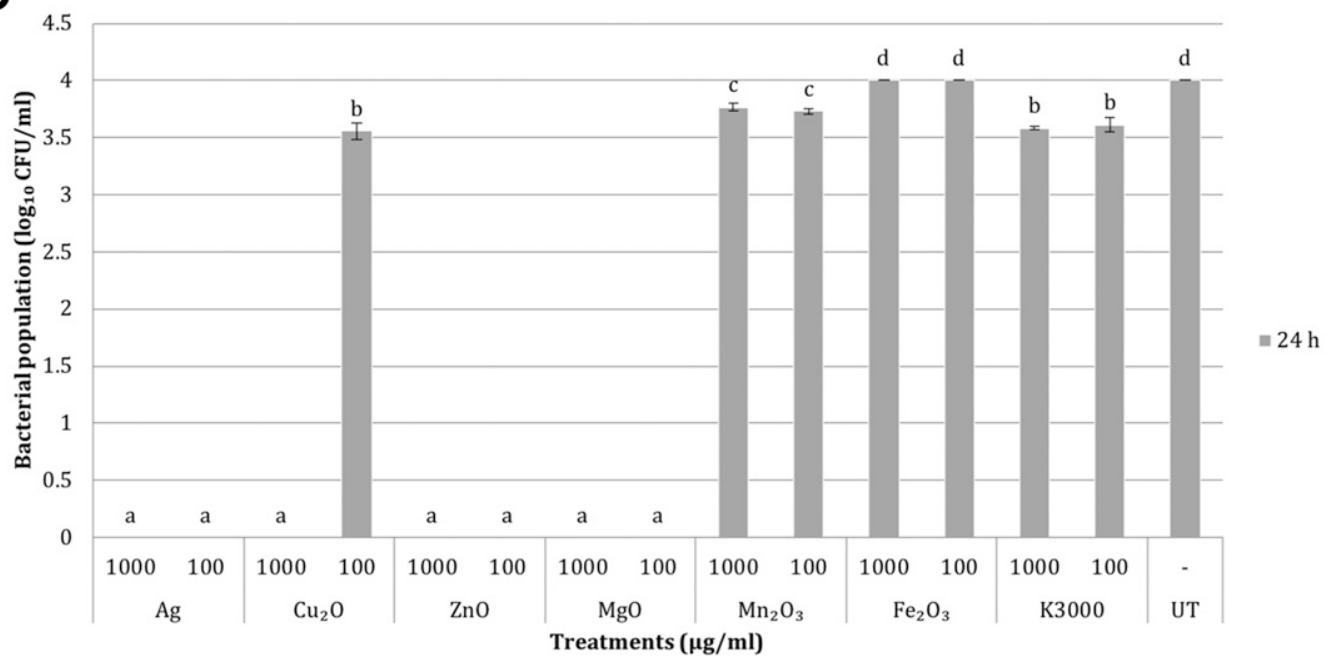

Fig. 1. In vitro inhibition of Cu-tolerant Xanthomonas perforans strain GEV485 following exposure to nanomaterials for 1,4 , and $24 \mathrm{~h}$. Treatments were as follows: $\mathrm{Ag}, \mathrm{Cu}_{2} \mathrm{O}, \mathrm{ZnO}, \mathrm{Fe}_{2} \mathrm{O}_{3}, \mathrm{MgO}$, and $\mathrm{Mn}_{2} \mathrm{O}_{3}$ nanoparticles at 1,000 and $100 \mu \mathrm{g} / \mathrm{ml}$; or Cu prepared from Kocide 3000 (K3000) at 1,000 (3.3 g/liter), and 100 $\mu \mathrm{g} / \mathrm{ml}(0.334 \mathrm{~g} /$ liter). The treatments were compared with water control (UT) at incubation times of A, $1 \mathrm{~h} ; \mathbf{B}, 4 \mathrm{~h}$; and $\mathbf{C}, 24 \mathrm{~h}$. Error bars indicate standard error of the mean. $P$ value of 0.05 was used in the IBM SPSS using Student-Newman-Keuls statistical analysis. 
bactericide (Kocide 3000), Nano- $\mathrm{Mn}_{2} \mathrm{O}_{3}$, or Nano- $\mathrm{Fe}_{2} \mathrm{O}_{3}$ at either concentration had minimal or no effect on bacterial populations as compared with the untreated control. The MIC and the MBC were 25 and $100 \mu \mathrm{g} / \mathrm{ml}$, respectively, after exposure to Nano-MgO for $4 \mathrm{~h}$ (Fig. 2).

For the Cu-sensitive strain X. perforans 91-118 (Fig. 3A to C), similar results were observed as with the $\mathrm{Cu}$-tolerant strain, except that significant antibacterial activity was also observed with both of the $\mathrm{Cu}$ compounds (Nano- $\mathrm{Cu}_{2} \mathrm{O}$ and Kocide 3000 ). Viable bacterial cells could not be recovered after $1 \mathrm{~h}$ (100\% reduction) (Fig. 3A) following treatment with the lower concentration $(100 \mu \mathrm{g} / \mathrm{ml})$ of Nano- $\mathrm{Cu}_{2} \mathrm{O}$, Kocide 3000, Nano-Ag, and Nano-ZnO. Again, Nano$\mathrm{Mn}_{2} \mathrm{O}_{3}$ or Nano- $\mathrm{Fe}_{2} \mathrm{O}_{3}$ had no effect on the bacterial populations. Based on the in vitro test with both strains, Nano-Ag, Nano-ZnO, Nano-MgO, and Nano- $\mathrm{Cu}_{2} \mathrm{O}$ all showed greater antibacterial activity than the $\mathrm{Cu}$ bactericide Kocide 3000 .

Morphological comparisons of $\mathrm{Cu}$-tolerant $X$. perforans GEV485 following exposure to Nano-MgO and controls. Untreated $X$. perforans cells that were negatively stained with uranyl acetate were observed using TEM (Fig. 4A1 to A4). The surface of the healthy $X$. perforans was smooth and showed typical characteristics of a rod shape, with an undamaged structure of the inner membrane and an intact, slightly wavy outer membrane (Fig. $4 \mathrm{~A} 2$ and A3). The bacterial cells treated with Nano-MgO at 100 $\mu \mathrm{g} / \mathrm{ml}$ (Fig. 4B1 to B4) were severely damaged, with a rough and folded surface (Fig. 4B2 and B3). The membrane was misshapen, with rough edges. The cells treated with the $\mathrm{Cu}$ bactericide, Kocide 3000 (DuPont), at $100 \mu \mathrm{g} / \mathrm{ml}$ (Fig. 4C1 to C4) were smooth and resembled the untreated healthy cells (Fig. 4C).

The effect of metallic oxide nanoparticles on bacterial spot disease severity under greenhouse conditions. In the first greenhouse experiment with the $\mathrm{Cu}$-tolerant strain $\mathrm{GEV} 485$ (Fig. 5A), all Nano- $\mathrm{Cu}_{2} \mathrm{O}$ concentrations and the two Nano-MgO concentrations $(1,000$ and $200 \mu \mathrm{g} / \mathrm{ml})$ significantly decreased disease severity compared with the grower standard ( $\mathrm{Cu}-\mathrm{EBDC})$ and the untreated control. For phytotoxicity, only Nano- $\mathrm{Cu}_{2} \mathrm{O}$ at $100 \mu \mathrm{g} / \mathrm{ml}$ was significantly different from the untreated control. The other treatments produced no overt signs of phytotoxicity (data not shown).

In the second greenhouse experiment (Fig. 5B), both $\mathrm{Nano}-\mathrm{Cu}_{2} \mathrm{O}$ and Nano-MgO concentrations as low as $200 \mu \mathrm{g} / \mathrm{ml}$ showed a significant reduction in disease severity compared with the untreated control. Compared with the grower's standard Cu-EBDC and Kocide 3000 alone, Nano- $\mathrm{Cu}_{2} \mathrm{O}$ at 1,000 and $500 \mu \mathrm{g} / \mathrm{ml}$ and Nano- $\mathrm{MgO}$ at $1,000 \mu \mathrm{g} / \mathrm{ml}$ showed reduced disease severity. Nano$\mathrm{ZnO}$ at both concentrations (1,000 and $200 \mu \mathrm{g} / \mathrm{ml})$ showed significantly reduced disease severity compared with the untreated control. However, this was not significant compared with the $\mathrm{Cu}-\mathrm{EBDC}$ and Kocide 3000 treatments. None of the treatments except for $\mathrm{Cu}_{2} \mathrm{O}$ at 1,000 and $500 \mu \mathrm{g} / \mathrm{ml}$ showed phytotoxicity compared with the untreated control (data not shown).

Comparison of metallic nanoparticles with $\mathrm{Cu}$ and $\mathrm{Cu}$ EBDC under field conditions for management of bacterial spot. Based on the results of greenhouse experiments (Fig. 5), Nano- $\mathrm{MgO}$ and Nano- $\mathrm{Cu}_{2} \mathrm{O}$ at 200 and $1,000 \mu \mathrm{g} / \mathrm{ml}$ were selected for field studies (Table 1) and were compared with $\mathrm{Cu}$-EBDC, the grower standard. In the first field experiment in fall 2015 in Quincy, FL, plants receiving either concentration of Nano-MgO $(1,000$ or $200 \mu \mathrm{g} / \mathrm{ml}$ ) had significantly less disease compared with the untreated control but were not different from the other treatments (Table 1). Both concentrations of Nano- $\mathrm{Cu}_{2} \mathrm{O}$ and $\mathrm{Cu}-\mathrm{EBDC}$ were not significantly different than the control. No phytotoxicity was observed for any of the treatments in this experiment.

In the 2016 spring trial in Wimauma, FL, plants treated with Nano-MgO at $200 \mu \mathrm{g} / \mathrm{ml}$ showed significantly reduced disease severity compare with the untreated control (Table 1), whereas the $1,000-\mu \mathrm{g} / \mathrm{ml}$ Nano- $\mathrm{MgO}$ treatment did not reduce disease severity compared with the untreated control. However, the $1,000-\mu \mathrm{g} / \mathrm{ml}$ Nano- $\mathrm{Cu}_{2} \mathrm{O}$ treatment significantly reduced disease severity compared with the untreated control.

In the 2016 spring trial in Quincy, both concentrations (1,000 and $200 \mu \mathrm{g} / \mathrm{ml}$ ) of the Nano-MgO and Nano- $\mathrm{Cu}_{2} \mathrm{O}$ treatments significantly reduced disease compared with the untreated control, whereas the grower's standard Cu-EBDC did not significantly reduce disease in the three field trials compared with the untreated control (Table 1). There were no significant negative impacts on marketable yield due to Nano-MgO treatments in any of the field trials (Table 2).

Accumulation of metals in harvested tomato fruit treated with metallic oxide nanoparticles. Fruit were collected 7 days after last application of test materials and analyzed for elemental composition. There were no significant differences

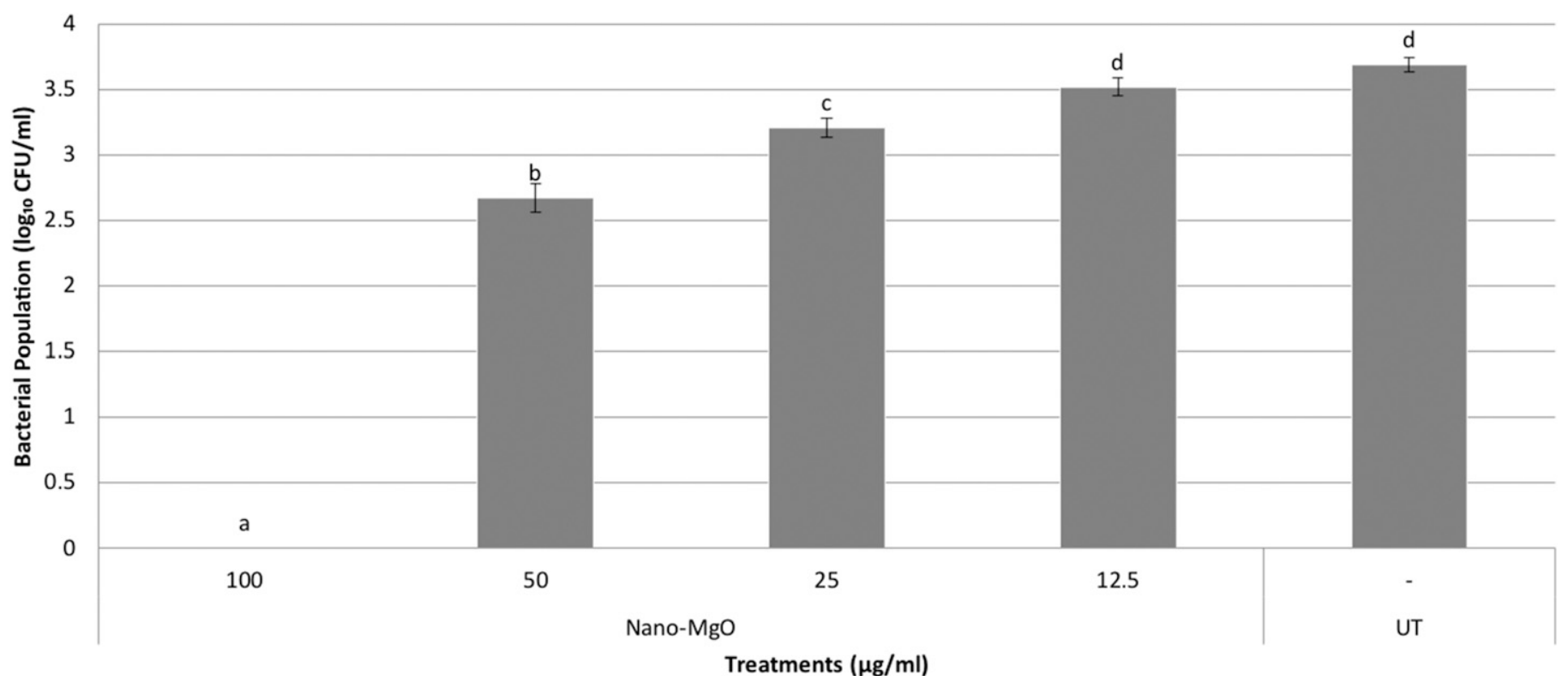

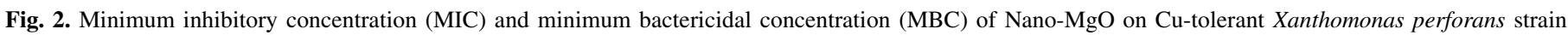

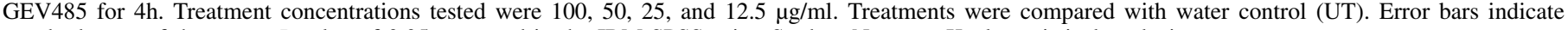
standard error of the mean. $P$ value of 0.05 was used in the IBM SPSS using Student-Newman-Keuls statistical analysis. 
for any of the elements when comparing the elemental concentration in dry fruit with different treatments (data not shown). As for fresh fruit (Table 3), both concentrations of Nano-MgO nanoparticle and the grower standard, $\mathrm{Cu}-\mathrm{EBDC}$, showed significantly lower $\mathrm{Al}$ concentrations relative to the untreated control, with $\mathrm{Al}$ content twice as high in untreated fruit as in the other three treatments. In addition, only the grower standard, $\mathrm{Cu}-\mathrm{EBDC}$, showed significantly higher $\mathrm{P}$ content in fruit compared with the controls. The P content was approximately $100 \mathrm{mg} / \mathrm{kg}$ higher than in untreated fresh weight. Interestingly, only Cu-EBDC showed significant $\mathrm{Cu}$ accumulation in whole fruit, and was $0.2 \mathrm{mg} / \mathrm{kg}$ more compared with the untreated control, whereas Nano-MgO and Nano- $\mathrm{Cu}_{2} \mathrm{O}$ at both concentrations did not differ from the untreated control. For the fruit collected 20 days after the last application of test particles (Table 4), Cu-EBDC showed significantly higher Al content in the whole fruit, with approximately $0.04 \mathrm{mg} / \mathrm{kg}$ more $\mathrm{Al}$ than in the untreated fruit (Table 4). However, Al did not significantly accumulate in either peel or flesh for the $\mathrm{Cu}$-EBDC treatment (Table 4). For other treatments, $\mathrm{Cu}_{2} \mathrm{O}$ at $1,000 \mu \mathrm{g} / \mathrm{ml}$ showed significantly lower $\mathrm{Al}$ content, to nearly half of that accumulated in the untreated fruit (Table 4). For $\mathrm{Cu}$ accumulation, fruit receiving $\mathrm{Cu}-\mathrm{EBDC}$ applications showed significantly greater $\mathrm{Cu}$ accumulation in whole fruit $(+0.22 \mathrm{mg} / \mathrm{kg}$ more $)$, peel $(+0.31 \mathrm{mg} / \mathrm{kg})$, and flesh $(+0.16 \mathrm{mg} / \mathrm{kg})$ (Table 4) compared with the untreated control. Fruit receiving Kocide 3000 showed significant $\mathrm{Cu}$ accumulation in the peel $(+0.27 \mathrm{mg} / \mathrm{kg})$.
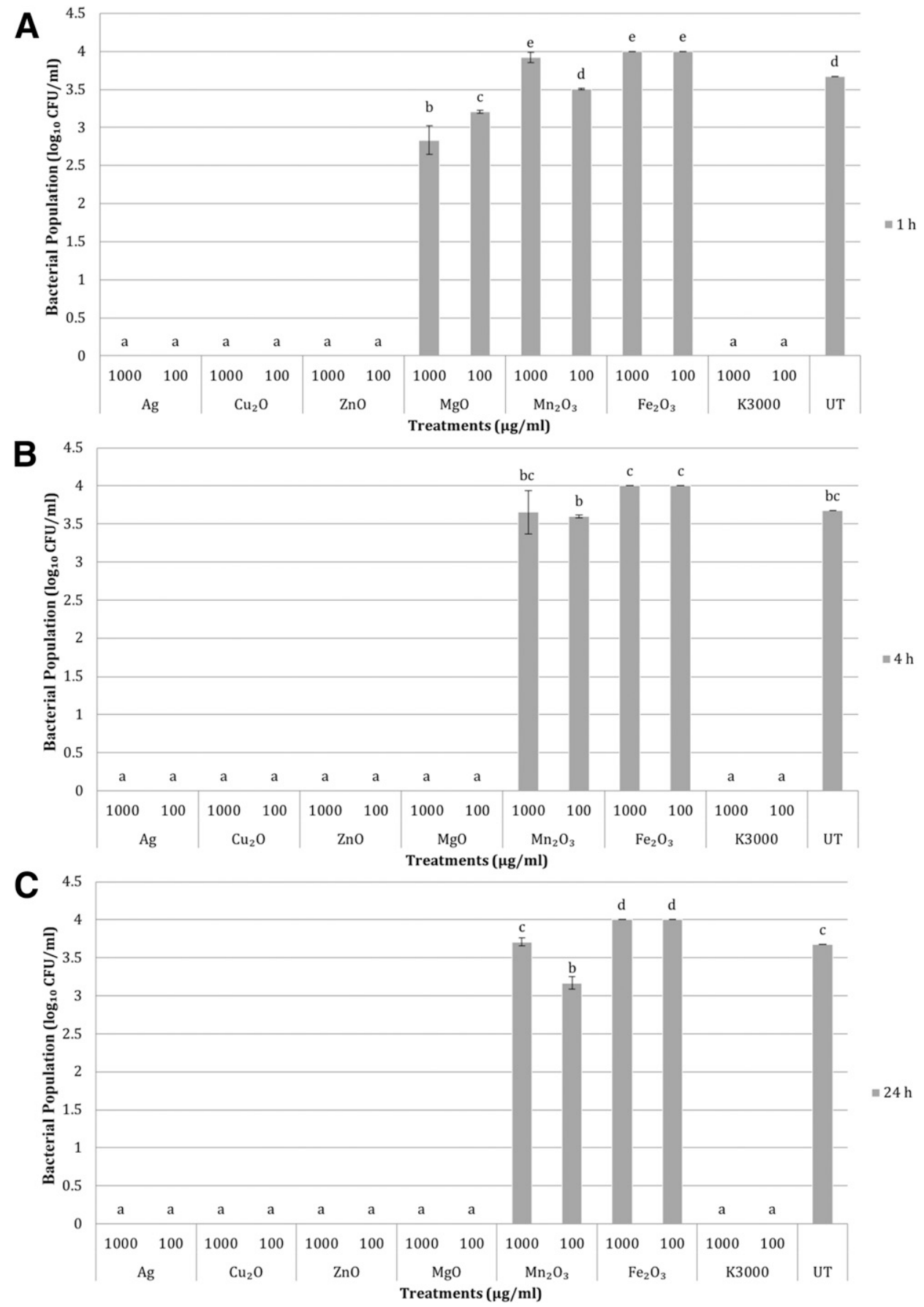

Fig. 3. In vitro inhibition of $\mathrm{Cu}$-sensitive Xanthomonas perforans strain 91-118 following exposure to various chemicals over time (1, 4, and $24 \mathrm{~h})$. Treatments were as follows: $\mathrm{Ag}, \mathrm{Cu}_{2} \mathrm{O}, \mathrm{ZnO}, \mathrm{Fe}_{2} \mathrm{O}_{3}, \mathrm{MgO}$, and $\mathrm{Mn}_{2} \mathrm{O}_{3}$ nanoparticles at 1,000 and $100 \mu \mathrm{g} / \mathrm{ml}$; or Cu prepared from Kocide 3000 (K3000) at 1,000 (3.3 g/liter), and $100 \mu \mathrm{g} / \mathrm{ml}$ ( $0.334 \mathrm{~g} /$ liter). Treatments were compared with water control (UT) at incubation times of A, $1 \mathrm{~h} ; \mathbf{B}, 4 \mathrm{~h}$; and $\mathbf{C}, 24 \mathrm{~h}$. Error bars indicate standard error of the mean. $P$ value of 0.05 was used in the IBM SPSS using Student-Newman-Keuls statistical analysis. 


\section{DISCUSSION}

In this study, for the first time, Nano-MgO was shown to have potential as an alternative to a $\mathrm{Cu}$ bactericide for bacterial spot management in tomato production because it yielded consistent reductions in disease severity, while other metal oxide nanoparticles, including Nano- $\mathrm{Cu}_{2} \mathrm{O}$, did not provide the same efficacy. Based on this research, Nano- $\mathrm{MgO}$ at 100 and $1,000 \mu \mathrm{g} / \mathrm{ml}$ controlled $\mathrm{Cu}$-tolerant and $\mathrm{Cu}$-sensitive $X$. perforans strains in the in vitro experiments. Nano- $\mathrm{MgO}$ compared with the conventional copper bactericide, Kocide 3000, was highly toxic to the $\mathrm{Cu}$ tolerant strain. Specifically, after $4 \mathrm{~h}$, Nano-MgO at $100 \mu \mathrm{g} / \mathrm{ml}$ significantly inhibited growth of the $\mathrm{Cu}$-tolerant strain, whereas Kocide 3000 had no impact at $1,000 \mu \mathrm{g} / \mathrm{ml}$ during the same exposure period. Nano- $\mathrm{Cu}_{2} \mathrm{O}$ also showed significant antibacterial ability toward the $\mathrm{Cu}$-tolerant strain in vitro. In addition, Nano- $\mathrm{ZnO}$

Nano-MgO treated

Kocide 3000 treated

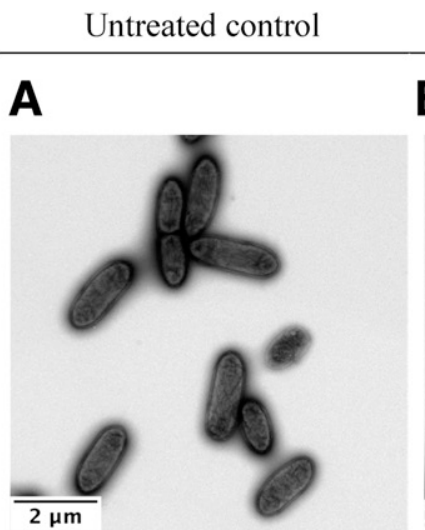

B1
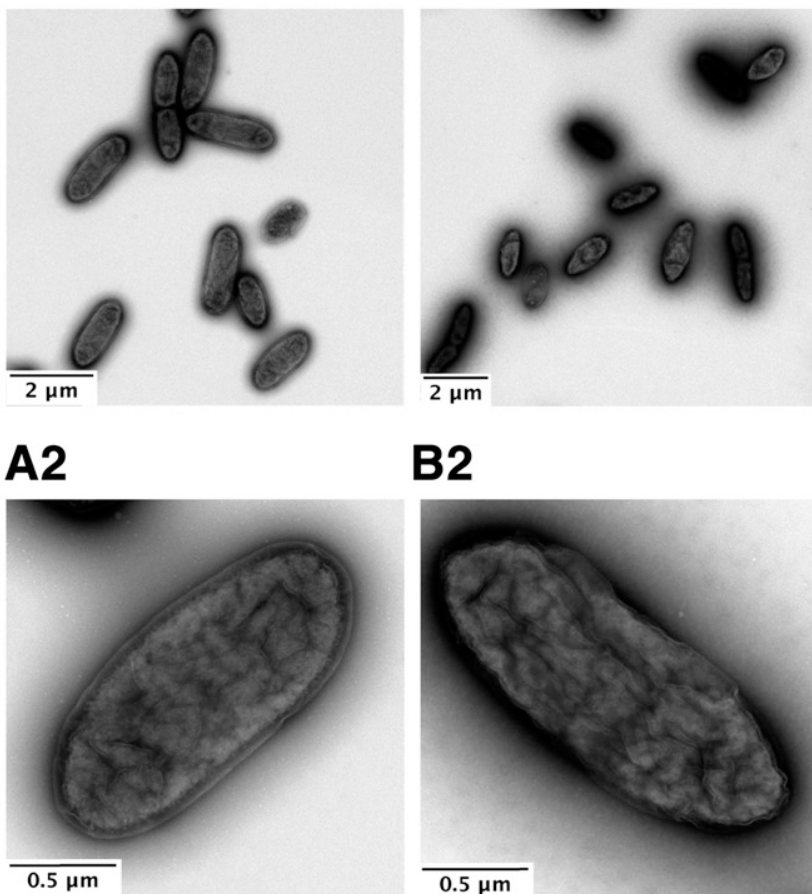

A3

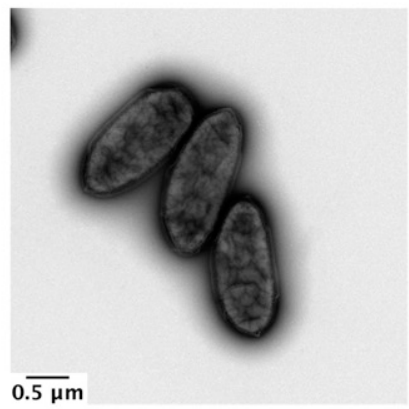

A4

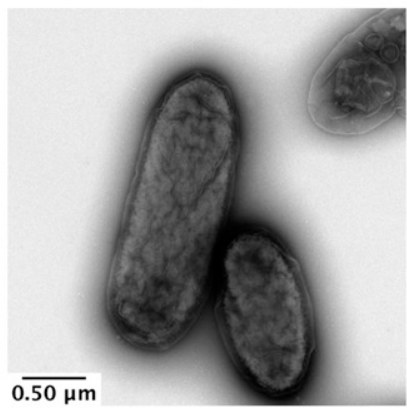

B2

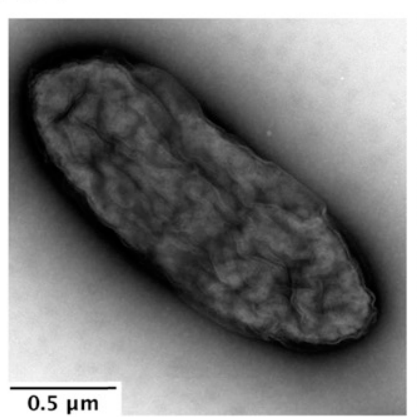

C2

\section{B3}

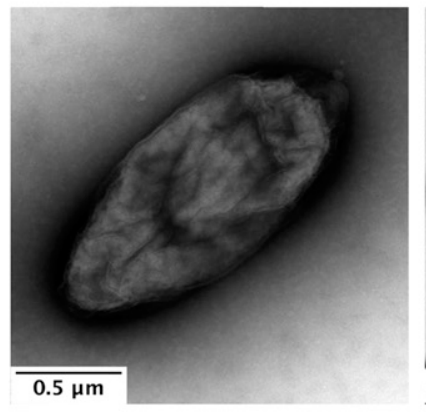

\section{B4}

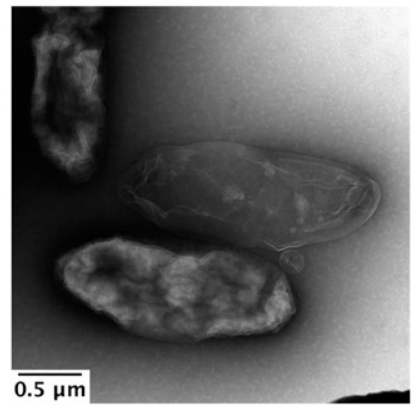

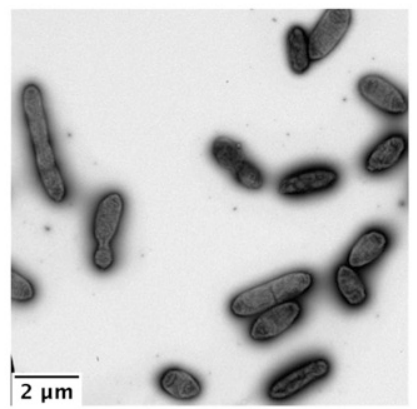

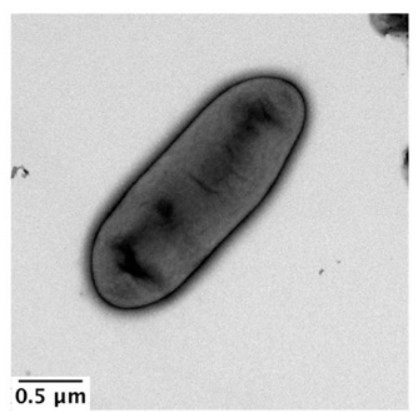

\section{C3}

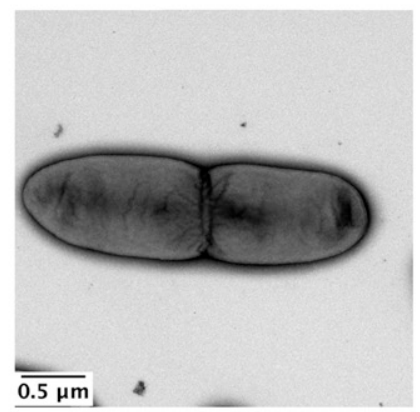

\section{C4}

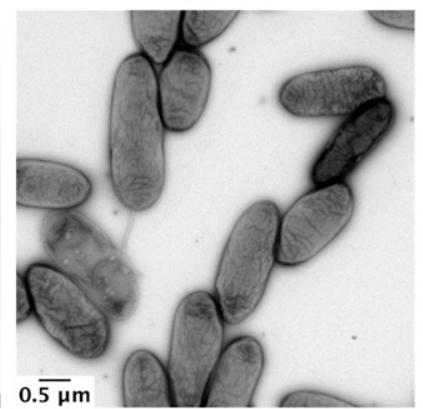

Fig. 4. Morphological analysis of Cu-tolerant Xanthomonas perforans GEV485 treated with $100 \mu \mathrm{g} / \mathrm{ml} \mathrm{Nano-MgO}$ with transmission electron microscopy. Untreated and the $\mathrm{Cu}$ bactericide Kocide 3000 were used as the controls. A, Untreated cells; B, Nano-MgO-treated cells; and C, Kocide 3000 (DuPont)-treated cells. 
also had significant antibacterial ability against both the strains used in the study. Although Nano- $\mathrm{Cu}_{2} \mathrm{O}$ did not have the same level of activity as Nano-MgO, it is interesting that the nanoform of $\mathrm{Cu}$ showed greater antibacterial activity than the conventional $\mathrm{Cu}$ bactericide. $\mathrm{Cu}$ nanoparticles are known to be more toxic than bulk particles to a range of species; however, the mechanism is unclear.

Nano-ZnO was interesting in that neither bacterial strain was recovered following exposure to Nano- $\mathrm{ZnO}$ at $1,000 \mu \mathrm{g} / \mathrm{ml}$ after $1 \mathrm{~h}$ and Nano- $\mathrm{ZnO}$ at $100 \mu \mathrm{g} / \mathrm{ml}$ after $4 \mathrm{~h}$ of incubation in the in vitro assay but the compound provided little disease control in the greenhouse study. Initially, Nano-ZnO showed some disease management potential in the early stages of the disease but symptoms developed rapidly afterward (data not shown). Nano-ZnO may still be a potential antibacterial material to manage bacterial spot disease when combined with other bactericides; however, this needs to be studied further. Nano-ZnO does not always show consistent disease management and sometimes caused phytotoxicity to the plants according to the former studies (Burman et al. 2013; Lin and Xing

A

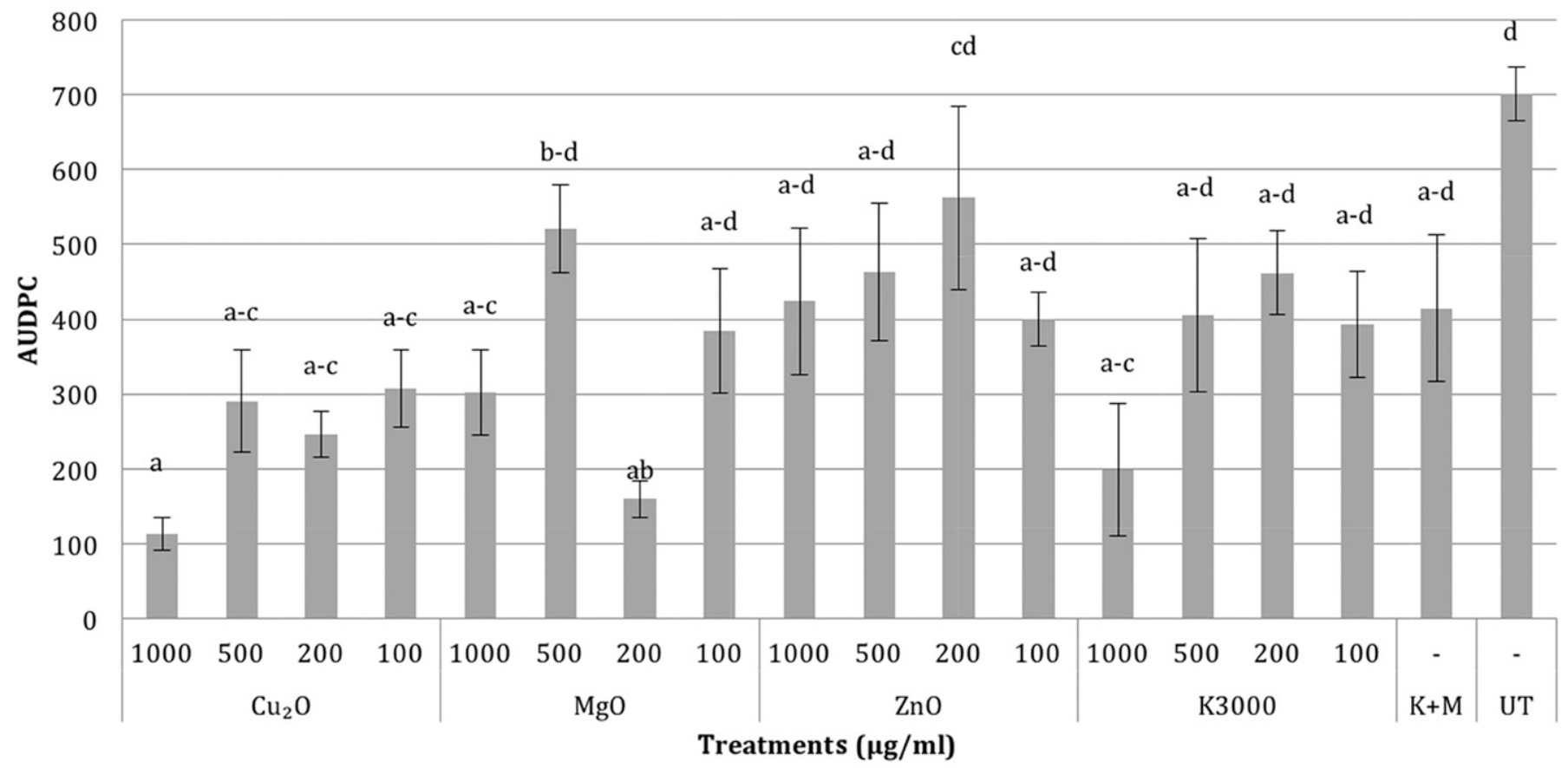

B

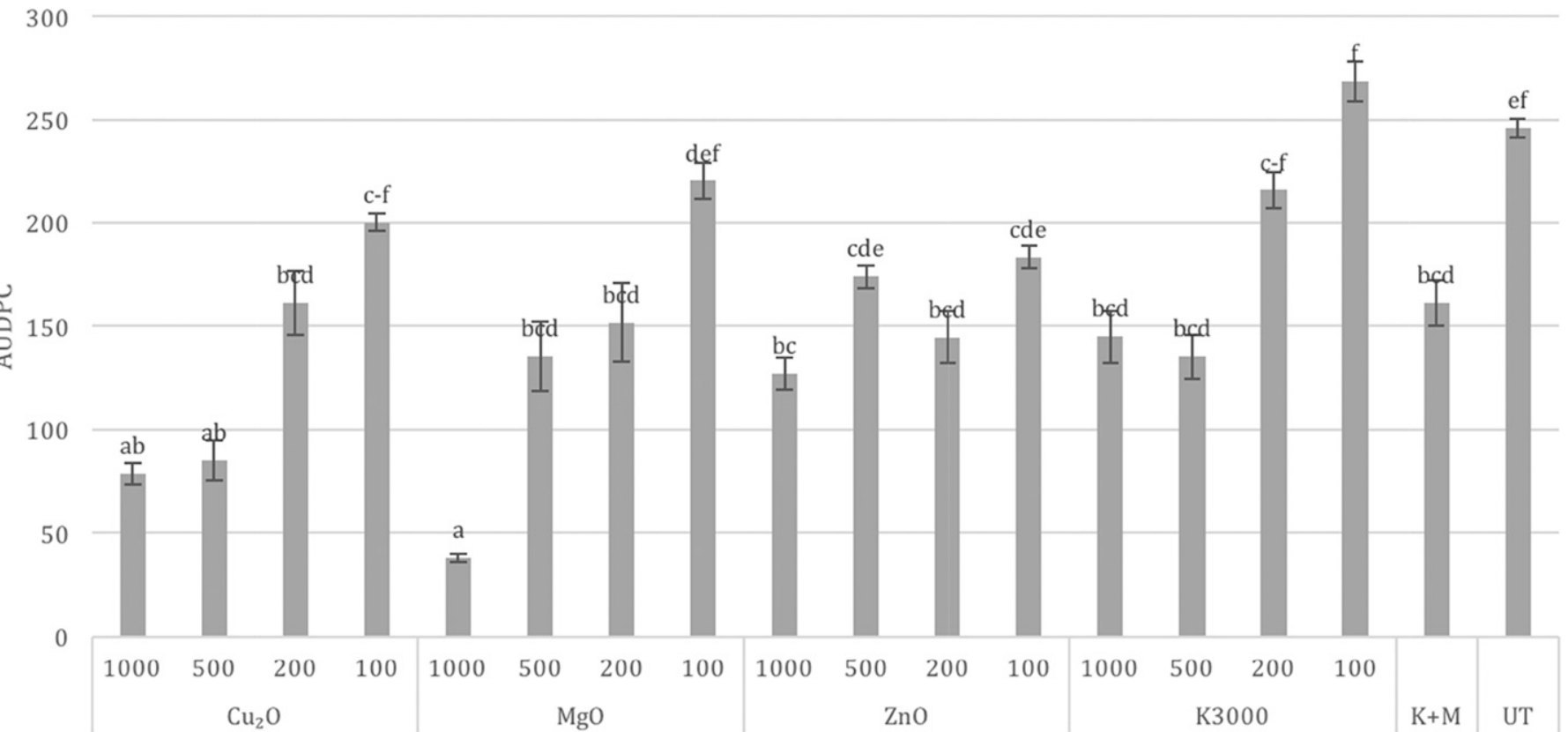

Treatments $(\mu \mathrm{g} / \mathrm{ml})$

Fig. 5. Management of bacterial spot of tomato in the greenhouse. Bonny Best tomato plants were sprayed with $\mathrm{Nano}^{-\mathrm{Cu}} \mathrm{u}_{2} \mathrm{O}, \mathrm{Nano}-\mathrm{MgO}$ or Nano- $\mathrm{ZnO}$ at 1,000 , 500,200 , or $100 \mu \mathrm{g} / \mathrm{ml}$; Cu prepared from Kocide 3000 (K3000) at 1,000 (3.3 g/liter), 500 (1.67 g/liter), $200(0.668 \mathrm{~g} / \mathrm{liter})$, and $100 \mu \mathrm{g} / \mathrm{ml}(0.334 \mathrm{~g} / \mathrm{liter})$; a combination of Kocide 3000 (2.1 g/liter) (K3000) and Penncozeb 75DF (1.2 g/liter) (Cu-ethylene-bis-dithiocarbamate [K+M]); or sterile tap water prior to inoculating with Cu-tolerant strain GEV 485 of Xanthomonas perforans. Experiments were conducted in A, fall 2015 and B, summer 2016 . Disease severity of bacterial spot of tomato in greenhouse conditions is expressed as area under disease progress curve (AUDPC). Error bars represent the standard error of the mean. $P$ value of 0.05 was used in the IBM SPSS Student-Newman-Keuls statistical analysis. 
TABLE 1. Comparison of magnesium oxide (Nano-MgO), and copper oxide $\left(\mathrm{Nano}-\mathrm{Cu}_{2} \mathrm{O}\right)$ nanomaterials with the grower standard $(\mathrm{Cu}$-ethylene-bis-dithiocarbamate [EBDC]) for control of bacterial spot disease severity (area under disease progress curve [AUDPC]) on tomato in three field experiments in Quincy and Wimauma, $\mathrm{FL}^{\mathrm{x}}$

\begin{tabular}{lcccc}
\hline & & \multicolumn{2}{c}{ AUDPC in different locations and seasons ${ }^{\mathrm{y}}$} \\
\cline { 3 - 5 } Treatment & $\begin{array}{c}\text { Rate } \\
(\mu \mathrm{g} / \mathrm{ml})\end{array}$ & $\begin{array}{c}\text { Quincy } \\
2015 \text { fall }\end{array}$ & $\begin{array}{c}\text { Wimauma 2016 } \\
\text { spring }\end{array}$ & $\begin{array}{c}\text { Quincy 2016 } \\
\text { spring }\end{array}$ \\
\hline $\mathrm{Nano}-\mathrm{Cu}_{2} \mathrm{O}$ & 1,000 & $987.4 \mathrm{ab}$ & $669.6 \mathrm{a}$ & $1,063.8 \mathrm{a}$ \\
$\mathrm{Nano}-\mathrm{Cu}_{2} \mathrm{O}$ & 200 & $930.4 \mathrm{ab}$ & $761.4 \mathrm{ab}$ & $877.7 \mathrm{a}$ \\
$\mathrm{Nano}-\mathrm{MgO}$ & 1,000 & $805.0 \mathrm{a}$ & $866.4 \mathrm{ab}$ & $913.5 \mathrm{a}$ \\
Nano-MgO & 200 & $836.9 \mathrm{a}$ & $580.1 \mathrm{a}$ & $853.6 \mathrm{a}$ \\
Kocide 3000 & 2,100 & $1,196.4 \mathrm{ab}$ & $972.1 \mathrm{ab}$ & $1,135.4 \mathrm{ab}$ \\
$\mathrm{Cu}-\mathrm{BBDC}$ & $\ldots$ & $1,092.9 \mathrm{ab}$ & $773.4 \mathrm{ab}$ & $1,188.0 \mathrm{ab}$ \\
Water & & $1,330.9 \mathrm{~b}$ & $1,136.8 \mathrm{~b}$ & $1,402.1 \mathrm{~b}$ \\
(untreated) & $\ldots$ & &
\end{tabular}

$\mathrm{x}$ Tomato cultivars were BHN602 in Quincy and HM1823 in Wimauma.

y Field trials were conducted in two locations and two seasons. AUDPC was calculated using the midpoint values of Horsfall-Barratt disease severity scale (Barratt and Horsfall 1945; Campbell and Madden 1990). Numbers followed by different letters in the same column had a significant difference $(P=0.05)$ based on Student-Newman-Keuls statistical analysis using the IBM SPSS program.

${ }^{\mathrm{z}} \mathrm{Cu}-\mathrm{EBDC}$ is composed of Kocide $3000(2,100 \mu \mathrm{g} / \mathrm{ml})$ and Penncozeb 75DF $(1,200 \mu \mathrm{g} / \mathrm{ml})$.

TABLE 2. Total marketable yield in three field experiments following treatment of tomato plants with magnesium oxide (Nano-MgO) and copper oxide (Nano- $\left.\mathrm{Cu}_{2} \mathrm{O}\right)$ nanomaterials, the grower standard $(\mathrm{Cu}$-ethylene-bis-dithiocarbamate $[\mathrm{EBDC}])$, and the untreated control in Quincy and Wimauma, FL ${ }^{\mathrm{w}}$

\begin{tabular}{|c|c|c|c|c|}
\hline \multirow[b]{2}{*}{ Treatment } & \multirow[b]{2}{*}{$\begin{array}{l}\text { Rate }(\mu \mathrm{g} / \\
\mathrm{ml})\end{array}$} & \multicolumn{3}{|c|}{$\begin{array}{c}\text { Marketable yield }(\mathrm{kg} / \mathrm{ha}) \text { in different locations } \\
\text { and seasons }{ }^{\mathrm{x}}\end{array}$} \\
\hline & & $\begin{array}{l}\text { Quincy } 2015 \\
\text { fall }\end{array}$ & $\begin{array}{l}\text { Wimauma } 2016 \\
\text { spring }\end{array}$ & $\begin{array}{c}\text { Quincy } 2016 \\
\text { spring }\end{array}$ \\
\hline Nano- $\mathrm{Cu}_{2} \mathrm{O}$ & 1,000 & $50,368.2$ & $26,228.5$ & $24,647.5$ \\
\hline Nano- $\mathrm{Cu}_{2} \mathrm{O}$ & 200 & $41,070.7$ & $32,926.8$ & $9,192.6$ \\
\hline Nano-MgO & 1,000 & $34,099.8$ & $32,061.9$ & $17,793.3$ \\
\hline Nano-MgO & 200 & $46,912.8$ & $30,296.9$ & $11,335.5$ \\
\hline Kocide 3000 & 2,100 & $44,932.9$ & $32,256.1$ & $20,357.2$ \\
\hline $\mathrm{Cu}-\mathrm{EBDC}^{\mathrm{y}}$ & $\ldots$ & $37,601.9$ & $32,132.5$ & $17,648.1$ \\
\hline $\begin{array}{l}\text { Water } \\
\text { (untreated) }\end{array}$ & $\ldots$ & $42,709.1$ & $28,708.4$ & $18,986.0$ \\
\hline $\begin{array}{l}\text { Significance } \\
\qquad(P=0.05)^{\mathrm{z}}\end{array}$ & $\ldots$ & NS & NS & NS \\
\hline
\end{tabular}

w Tomato cultivars were BHN602 in Quincy and HM1823 in Wimauma.

${ }^{x}$ Field trials took place in two locations and two seasons.

y $\mathrm{Cu}-\mathrm{EBDC}$ is composed of Kocide $3000(2,100 \mu \mathrm{g} / \mathrm{ml})$ and Penncozeb 75DF $(1,200 \mu \mathrm{g} / \mathrm{ml})$.

$\mathrm{z}$ None of the treatments had significant yield impact compared with the water treatment $(P=0.05)$ based on Student-Newman-Keuls statistical analysis using the IBM SPSS program; NS = not significant.
2007). The particle concentration, rate of ion release or particle dissolution, and plant species could be major factors controlling the efficacy of Nano-ZnO.

TEM was useful in demonstrating that exposure of bacterial cells of a Cu-tolerant bacterium to a suspension of Nano-MgO compared with exposure to a $\mathrm{Cu}$ bactericide suspension resulted in structural changes in the bacterial cells. Following exposure to Nano-MgO at $100 \mu \mathrm{g} / \mathrm{ml}$, the bacterial cells were distorted compared with healthy-looking cells following exposure to tap water or the $\mathrm{Cu}$ bactericide suspension. Some of the cells treated with Nano-MgO showed gentle leakage and fragments around the cells (Bode et al. 1993; Li et al. 2010; Paret et al. 2012). Thus, exposure of $X$. perforans cells to a Nano-MgO suspension led to pronounced changes in cell morphology. Based on the 50 micrographs analyzed in our study, approximately $90 \%$ of the cells showed morphological changes after exposure to Nano$\mathrm{MgO}$ at $100 \mu \mathrm{g} / \mathrm{ml}$ compared with nearly all cells appearing healthy in controls (Kocide 3000-treated cells and untreated control) (data not shown). The in vitro MIC and MBC studies confirmed these observations of the antibacterial activity of Nano-MgO. Further experiments are needed to understand the mode of action of Nano$\mathrm{MgO}$ compared with other metallic nanoparticles.

In the greenhouse experiments, application of Nano-MgO and Nano- $\mathrm{Cu}_{2} \mathrm{O}$ at $200 \mu \mathrm{g} / \mathrm{ml}$ to tomato plants significantly reduced bacterial spot disease severity compared with $\mathrm{Cu}-\mathrm{EBDC}$ and the untreated controls $(P=0.05)$. Although greenhouse experiments provide reproducible results under controlled conditions, they do not take into account the diverse environmental factors that could influence bactericide efficacy under field conditions. Therefore, field experiments were conducted in this study. In the two field experiments in Quincy, FL and Wimauma, FL, application of Nano- $\mathrm{Cu}_{2} \mathrm{O}$ did not significantly reduce disease compared with the untreated control. Nano- $\mathrm{MgO}$ at $200 \mu \mathrm{g} / \mathrm{ml}$ provided a significant reduction in bacterial spot severity compared with the untreated control $(P=0.05)$, with no signs of phytotoxicity in all field experiments. In addition, the $200-\mu \mathrm{g} / \mathrm{ml}$ rate of $\mathrm{Nano}-\mathrm{MgO}$ nanoparticles was comparable with $\mathrm{Cu}$-EBDC for disease management. There was no impact on the yield between any of the treatments.

The metallic $\mathrm{Cu}$ concentration currently used for controlling bacterial spot in tomato fields is approximately $540 \mu \mathrm{g} / \mathrm{ml}$. That is approximately two times higher than the level of $\mathrm{Mg}$ from the Nano$\mathrm{MgO} 200-\mu \mathrm{g} / \mathrm{ml}$ treatment (metallic $\mathrm{MgO}$ concentration $=120 \mu \mathrm{g}$ / $\mathrm{ml}$ ). In addition, Nano-MgO application would help to moderate metal accumulation in the field. If commercialized, using Nano$\mathrm{MgO}$ as an alternative could help to relieve the pressure of potential $\mathrm{Cu}$ accumulation in the soil (Wightwick et al. 2008) and further development of $\mathrm{Cu}$-tolerant pathogens.

This study indicates that Nano-MgO could be a good chemical alternative to $\mathrm{Cu}$ bactericides. There are two important approaches for controlling bacterial spot of tomato in the field: reducing inoculum

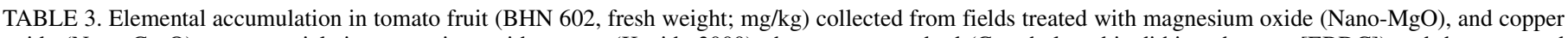

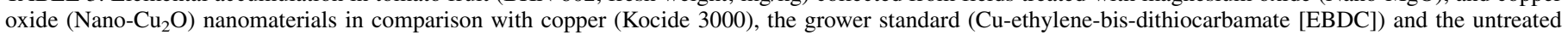
control in Quincy from the first harvest (7 days from the last application) in fall 2015 trial $^{\mathrm{x}}$

\begin{tabular}{|c|c|c|c|c|c|c|c|c|c|c|c|c|c|c|}
\hline \multirow[b]{2}{*}{ Treatment } & \multirow{2}{*}{$\frac{\text { Rate }}{(\mu \mathrm{g} / \mathrm{ml})}$} & \multicolumn{13}{|c|}{ Elemental accumulation in fruit $(\mathrm{mg} / \mathrm{kg} \mathrm{FW})^{\mathrm{y}}$} \\
\hline & & $\mathrm{Al}$ & $\mathrm{B}$ & $\mathrm{Ca}$ & $\mathrm{Cu}$ & $\mathrm{Fe}$ & $\mathrm{K}$ & $\mathrm{Mg}$ & $\mathrm{Mn}$ & Mo & $\mathrm{Na}$ & $\mathrm{P}$ & $\mathrm{S}$ & $\mathrm{Zn}$ \\
\hline Nano- $\mathrm{Cu}_{2} \mathrm{O}$ & 1,000 & 0.12 & 0.82 & 84.65 & 0.72 & 2.58 & $2,712.5$ & 129.2 & 3.01 & 0.03 & 18.27 & $286.9 *$ & 135.8 & 1.76 \\
\hline Nano- $\mathrm{Cu}_{2} \mathrm{O}$ & 200 & 0.11 & 0.83 & 71.35 & 0.66 & 2.68 & $2,677.5$ & 134.3 & 2.67 & 0.03 & 21.60 & $295.9 *$ & 129.4 & 1.74 \\
\hline Nano-MgO & 1,000 & $0.07 *$ & 0.75 & 74.62 & 0.64 & 2.42 & $2,653.2$ & 133.3 & 2.78 & 0.02 & 20.27 & 262.1 & 128.8 & 1.66 \\
\hline Nano-MgO & 200 & $0.07 *$ & 0.75 & 75.23 & 0.67 & 2.68 & $2,565.4$ & 129.4 & 2.47 & 0.03 & 19.65 & 276.9 & 128.5 & 1.86 \\
\hline Kocide 3000 & 2,100 & $0.07 *$ & 0.85 & 67.23 & $0.83 *$ & 3.00 & $2,815.3$ & 145.5 & 2.99 & 0.03 & 24.41 & $309.7 *$ & 141.9 & 1.95 \\
\hline $\mathrm{Cu}-\mathrm{EBDC}^{\mathrm{z}}$ & $\ldots$ & $0.09 *$ & 0.77 & 72.58 & 0.77 & 2.78 & $2,620.6$ & 126.7 & 2.89 & 0.03 & 24.87 & 272.9 & 128.7 & 1.81 \\
\hline Water (untreated) & $\ldots$ & 0.15 & 0.76 & 73.22 & 0.58 & 2.59 & $2,523.8$ & 120.2 & 2.11 & 0.03 & 18.60 & 212.0 & 116.3 & 1.48 \\
\hline Significance $(P=0.05)$ & $\ldots$ & Yes & NS & NS & Yes & NS & NS & NS & NS & NS & NS & Yes & NS & NS \\
\hline
\end{tabular}

${ }^{x}$ All of the samples were evaluated with inductively coupled plasma emission spectroscopy for elemental accumulation.

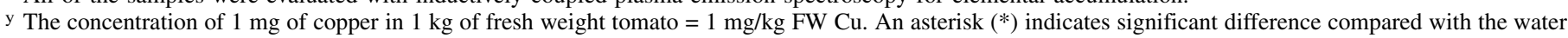
treatment $(P=0.05)$ based on Student-Newman-Keuls statistical analysis using the IBM SPSS program; NS = not significant.

${ }^{\mathrm{z}} \mathrm{Cu}-\mathrm{EBDC}$ is composed of Kocide $3000(2,100 \mu \mathrm{g} / \mathrm{ml})$ and Penncozeb 75DF $(1,200 \mu \mathrm{g} / \mathrm{ml})$. 


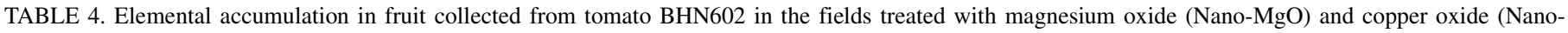

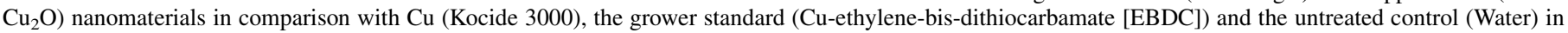
Quincy from the second harvest (20 days from the last application) in the fall 2015 trial $^{\mathrm{w}}$

\begin{tabular}{|c|c|c|c|c|c|c|c|c|c|c|c|c|c|c|}
\hline \multirow[b]{2}{*}{ Treatment } & \multirow{2}{*}{$\frac{\text { Rate }}{(\mu \mathrm{g} / \mathrm{ml})}$} & \multicolumn{13}{|c|}{ Elemental accumulation in fruit $(\mathrm{mg} / \mathrm{kg} \mathrm{FW})^{\mathrm{x}}$} \\
\hline & & $\mathrm{Al}$ & B & $\mathrm{Ca}$ & $\mathrm{Cu}$ & $\mathrm{Fe}$ & $\mathrm{K}$ & $\mathrm{Mg}$ & $\mathrm{Mn}$ & Mo & $\mathrm{Na}$ & $\mathrm{P}$ & $\mathrm{S}$ & $\mathrm{Zn}$ \\
\hline \multicolumn{15}{|l|}{ Whole fruit } \\
\hline Nano-MgO & 1,000 & 0.08 & 0.66 & 70.19 & 0.58 & 2.26 & $2,053.04$ & 114.03 & 2.72 & 0.02 & 15.63 & 238.99 & 110.77 & 1.57 \\
\hline Nano-MgO & 200 & 0.06 & 0.65 & 73.88 & 0.51 & 2.10 & $2,031.10$ & 107.87 & 2.31 & 0.02 & 15.66 & 218.88 & 108.01 & 1.54 \\
\hline Kocide 3000 & 2,100 & $0.12 *$ & 0.77 & 58.82 & 0.90 & 2.76 & $2,279.24$ & 123.88 & 2.65 & 0.02 & 23.54 & 268.36 & 123.90 & 1.98 \\
\hline Significance ${ }^{\mathrm{z}}$ & $\ldots$ & Yes & NS & NS & NS & NS & NS & NS & NS & NS & NS & NS & NS & NS \\
\hline \multicolumn{15}{|l|}{ Peel } \\
\hline Nano- $\mathrm{Cu}_{2} \mathrm{O}$ & 1,000 & $0.04 *$ & 0.72 & 81.78 & 0.64 & 2.42 & $2,353.60$ & 124.66 & 1.73 & 0.02 & 15.83 & 232.50 & 116.95 & 1.66 \\
\hline Nano- $\mathrm{Cu}_{2} \mathrm{O}$ & 200 & 0.06 & 0.66 & 75.54 & 0.52 & 2.32 & $2,193.72$ & 118.52 & 1.72 & 0.03 & 16.71 & 234.83 & 117.43 & 1.46 \\
\hline Nano-MgO & 1,000 & 0.06 & 0.66 & 76.07 & 0.50 & 2.25 & $2,072.64$ & 112.03 & 2.29 & 0.02 & 14.86 & 230.96 & 113.79 & 1.51 \\
\hline Nano-MgO & 200 & 0.05 & 0.62 & 69.43 & 0.43 & 2.15 & $2,094.00$ & 94.37 & 1.68 & 0.02 & 14.29 & 205.72 & 106.84 & 1.46 \\
\hline Kocide 3000 & 2,100 & 0.10 & 0.83 & 71.90 & $0.86^{*}$ & 2.56 & $2,284.95$ & 120.08 & 2.38 & 0.02 & 20.24 & 249.71 & 123.46 & 1.88 \\
\hline Nano- $\mathrm{Cu}_{2} \mathrm{O}$ & 200 & 0.03 & 0.63 & 45.74 & 0.72 & 2.40 & $1,951.79$ & 115.65 & 2.45 & 0.03 & 19.63 & 276.48 & 113.78 & 1.53 \\
\hline Nano-MgO & 1,000 & 0.05 & 0.64 & 50.87 & 0.73 & 2.45 & $1,818.84$ & 113.47 & 3.17 & 0.02 & 15.92 & 273.97 & 107.05 & 1.66 \\
\hline Nano-MgO & 200 & 0.04 & 0.63 & 55.98 & 0.69 & 2.51 & $1,902.14$ & 123.72 & 2.75 & 0.02 & 17.46 & 252.12 & 113.87 & 1.62 \\
\hline Kocide 3000 & 2,100 & 0.08 & 0.70 & 43.65 & 1.04 & 3.14 & $2,091.54$ & 134.95 & 3.49 & 0.02 & 24.98 & 329.50 & 129.64 & 1.96 \\
\hline Cu-EBDC ${ }^{y}$ & $\ldots$ & 0.05 & 0.70 & 52.05 & 0.90 & 2.82 & $2,075.94$ & 137.34 & 3.90 & 0.03 & 24.12 & 322.98 & 123.64 & 1.80 \\
\hline Water & $\ldots$ & 0.10 & 0.66 & 56.01 & 0.88 & 2.63 & $1,978.23$ & 132.40 & 2.97 & 0.02 & 16.53 & 268.30 & 113.52 & 1.73 \\
\hline Significance ${ }^{\mathrm{z}}$ & $\ldots$ & NS & NS & NS & NS & NS & NS & NS & NS & NS & NS & NS & NS & NS \\
\hline
\end{tabular}

${ }^{\mathrm{w}}$ In addition to whole-fruit samples, flesh, and peel samples were also collected separately. All of the samples were evaluated with inductively coupled plasma emission spectroscopy for elemental accumulation.

${ }^{\mathrm{x}}$ The concentration of $1 \mathrm{mg}$ of copper in $1 \mathrm{~kg}$ of fresh weight tomato $=1 \mathrm{mg} / \mathrm{kg} \mathrm{FW} \mathrm{Cu}$. An asterisk (*) indicates significant difference compared with water treatment $(P=0.05)$ based on Student-Newman-Keuls statistical analysis using the IBM SPSS program; NS $=$ not significant.

y $\mathrm{Cu}$-EBDC is composed of Kocide $3000(2,100 \mu \mathrm{g} / \mathrm{ml})$ and Penncozeb 75DF $(1,200 \mu \mathrm{g} / \mathrm{ml})$.

z Significance at $P=0.05$.

and minimizing plant susceptibility (Momol et al. 2002). Nano-MgO could reduce inoculum in the field with its antibacterial ability. In addition, $\mathrm{MgO}$ would be a more sustainable treatment option in that $\mathrm{MgO}$, unlike copper, is not on the list of Environmental Protection Agency Toxic Release Inventory Program or in the Integrated Risk Information System. The Food and Drug Administration also views magnesium oxide as a generally recognized as safe compound (Clydesdale 1997). As a result, if commercialized, Nano-MgO can be potentially be applied as an alternative to $\mathrm{Cu}$ in Integrated Pest Management programs to reduce inoculum. Also, potentially, it could be combined with a plant defense activator or with biocontrol agents; however, this needs to be studied further. In this scenario, selective pressure on the development of Cu-tolerant $X$. perforans in the field would also be reduced.

In the elemental accumulation study, analysis of fresh fruit from the first harvest revealed that only $\mathrm{Cu}$-EBDC had significantly greater $\mathrm{Cu}$ accumulation in whole fruit, and was $0.2 \mathrm{mg} / \mathrm{kg}(36 \%)$ more than the untreated control. For the fruit collected 7 days after the last application, treatments with $\mathrm{Cu}-\mathrm{EBDC}$ had significantly greater $\mathrm{Cu}$ accumulation in whole fruit and flesh compared with the untreated control. In addition, fruit receiving Kocide 3000 showed significant $\mathrm{Cu}$ accumulation in the peel compared with the untreated control. None of the other treatments, including $\mathrm{MgO}$ and $\mathrm{Cu}_{2} \mathrm{O}$ nanoparticles, had significantly greater $\mathrm{Cu}$ or $\mathrm{Mg}$ accumulation in fruit compared with the untreated control. $\mathrm{Cu}$ is an essential element for mammals and plants; however, elevated $\mathrm{Cu}$ levels may be toxic (Gaetke and Chow 2003). In humans, the estimated lethal dose of $\mathrm{Cu}$ in an untreated adult is 10 to $20 \mathrm{~g}$ (Gaetke and Chow 2003; Winge and Mehra 1990). In our experiment, $0.2 \mathrm{mg}$ more $\mathrm{Cu}$ per kilogram fresh weight of tomato fruit accumulated in fruit in which the grower standard $\mathrm{Cu}$-EBDC was applied compared with the untreated control. In this scenario, consumption of tomato treated with $\mathrm{Cu}$-EBDC might lead to more $\mathrm{Cu}$ exposure for customers but the level is still well within the daily dietary limits. In other words, one would need to consume 10 to $20 \mathrm{~kg}$ of $\mathrm{Cu}$ bactericide-treated tomato in a day to achieve a toxic dose.

This study is the first study that shows the potential for developing $\mathrm{MgO}$-based nanoparticles for management of bacterial spot of tomato with no significant increase in elemental accumulation in fruit. Importantly, significant antibacterial activity was achieved in this study in spite of the fact that the material was present in an uncharacterized, nondisperse, and heterogeneous solution. Because the nanoparticles were likely aggregated, the antibacterial agent might have actually limited contact with the pathogen. This may explain why there was variation in the greenhouse and in field experiments, with the higher concentration tending to have greater standard deviations than the lower concentration. This phenomenon of aggregation fit the observation in the previous study by Sawai (2003) that the antibacterial ability is contact dependent between $\mathrm{MgO}$ nanoparticles and the target bacteria. This highlights the importance of developing $\mathrm{MgO}$ formulations as a more homogeneous suspension, possibly through the addition of surface coatings, functional groups, or polymers to control particle dissolution. This type of formulated $\mathrm{MgO}$ nanoparticle would likely result in an effective antibacterial agent that could be used as an alternative to currently available bactericide strategies.

\section{ACKNOWLEDGMENTS}

We thank the farm crew at North Florida Research and Education Center and Gulf Coast Research and Education Center for the support in field preparation and management of the trials, and G. V. Minsavage and R. E. Stall for supporting greenhouse experiments. 


\section{LITERATURE CITED}

Aruoja, V., Dubourguier, H.-C., Kasemets, K., and Kahru, A. 2009. Toxicity of nanoparticles of $\mathrm{CuO}, \mathrm{ZnO}$ and $\mathrm{TiO} 2$ to microalgae Pseudokirchneriella subcapitata. Sci. Total Environ. 407:1461-1468.

Averett, S. B., and Averett, D. R. 2015. Titanium Dioxide Photocatalytic Compositions and Uses Thereof. Online publication. Google Patents. https://patents.google.com/patent/US8609121B2/en Link

Azam, A., Ahmed, A. S., Oves, M., Khan, M., and Memic, A. 2012. Sizedependent antimicrobial properties of $\mathrm{CuO}$ nanoparticles against Grampositive and-negative bacterial strains. Int. J. Nanomedicine 7:3527-3535.

Barratt, R., and Horsfall, J. 1945. An improved grading system for measuring plant disease. (Abstr.) Phytopathology 35:655.

Bhainsa, K. C., and D'Souza, S. F. 2006. Extracellular biosynthesis of silver nanoparticles using the fungus Aspergillus fumigatus. Colloids Surf. B Biointerfaces 47:160-164.

Bode, G., Mauch, F., and Malfertheiner, P. 1993. The coccoid forms of Helicobacter pylori. Criteria for their viability. Epidemiol. Infect. 111:483-490.

Burman, U., Saini, M., and Kumar, P. 2013. Effect of zinc oxide nanoparticles on growth and antioxidant system of chickpea seedlings. Toxicol. Environ. Chem. 95:605-612.

Campbell, C. L., and Madden, L. V. 1990. Introduction to Plant Disease Epidemiology. John Wiley \& Sons, New York.

Clydesdale, F. M. 1997. A proposal for the establishment of scientific criteria for health claims for functional foods. Nutr. Rev. 55:413-422.

Cooksey, D. A., Azad, H. R., Cha, J.-S., and Lim, C.-K. 1990. Copper resistance gene homologs in pathogenic and saprophytic bacterial species from tomato. Appl. Environ. Microbiol. 56:431-435.

Cosentino, S., Tuberoso, C. I. G., Pisano, B., Satta, M., Mascia, V., Arzedi, E., and Palmas, F. 1999. In-vitro antimicrobial activity and chemical composition of Sardinian thymus essential oils. Lett. Appl. Microbiol. 29:130-135.

Freeman, J. H., McAvoy, E. J., Boyd, N., Dittmar, P. J., Ozores-Hampton, M., Smith, H. A., Vallad, G. E., and Webb, S. E. 2014. Tomato production. Pages 183-204 in: 2014-2015 Vegetable and Small Fruit Production Handbook of Florida.

Gaetke, L. M., and Chow, C. K. 2003. Copper toxicity, oxidative stress, and antioxidant nutrients. Toxicology 189:147-163.

Hoseinzadeh, E., Makhdoumi, P., Taha, P., Hossini, H., Stelling, J., Kamal, M. A. and Ashraf, G. M. 2017. A review on nano-antimicrobials: Metal nanoparticles, methods and mechanisms. Curr. Drug Metab. 18:120-128.

Huang, L., Li, D.-Q., Lin, Y.-J., Wei, M., Evans, D. G., and Duan, X. 2005. Controllable preparation of Nano-MgO and investigation of its bactericidal properties. J. Inorg. Biochem. 99:986-993.

Jones, J. B., and Jones, J. P. 1985. The effect of bactericides, tank mixing time and spray schedule on bacterial leaf spot of tomato. Proc. Fla. State Hortic. Soc. 98:244-247.

Jones, J. B., Lacy, G. H., Bouzar, H., Stall, R. E., and Schaad, N. W. 2004. Reclassification of the xanthomonads associated with bacterial spot disease of tomato and pepper. Syst. Appl. Microbiol. 27:755-762.

Jones, J. B., Vallad, G. E., Iriarte, F. B., Obradović, A., Wernsing, M. H., Jackson, L. E., Balogh, B., Hong, J. C., and Momol, M. T. 2012. Considerations for using bacteriophages for plant disease control. Bacteriophage 2:e23857.

Kelley, W. T., Boyhan, G. E., Harrison, K. A., Sumner, P. E., Langston, D. B., Sparks, A. N., Culpepper, S., Hurst, W. C., and Fonsah, E. G. 2010. Commercial Tomato Production Handbook. Online publication. University of Georgia Cooperative Extension. http://extension.uga.edu/publications/detail.html? number $=$ B $1312 \&$ title $=$ Commercial $\% 20$ Tomato $\% 20$ Production $\% 20$ Handbook

Li, W.-R., Xie, X.-B., Shi, Q.-S., Zeng, H.-Y., You-Sheng, O.-Y., and Chen, Y.-B. 2010. Antibacterial activity and mechanism of silver nanoparticles on Escherichia coli. Appl. Microbiol. Biotechnol. 85:1115-1122.

Lin, D., and Xing, B. 2007. Phytotoxicity of nanoparticles: Inhibition of seed germination and root growth. Environ. Pollut. 150:243-250.

Lok, C.-N., Ho, C.-M., Chen, R., He, Q.-Y., Yu, W.-Y., Sun, H., Tam, P. K.-H., Chiu, J.-F., and Che, C.-M. 2007. Silver nanoparticles: Partial oxidation and antibacterial activities. JBIC J. Biol. Inorganic Chem. 12:527-534.

Marambio-Jones, C., and Hoek, E. M. 2010. A review of the antibacterial effects of silver nanomaterials and potential implications for human health and the environment. J. Nanoparticle Res. 12:1531-1551.

Marco, G. M., and Stall, R. E. 1983. Control of bacterial spot of pepper initiated by strains of Xanthomonas campestris pv. vesicatoria that differ in sensitivity to copper. Plant Dis. 67:779-781.

Mattina, M. I., Lannucci-Berger, W., Musante, C., and White, J. C. 2003. Concurrent plant uptake of heavy metals and persistent organic pollutants from soil. Environ. Pollut. 124:375-378.

McAvoy, T., Freeman, J. H., Rideout, S. L., Olson, S. M., and Paret, M. L. 2012. Evaluation of grafting using hybrid rootstocks for management of bacterial wilt in field tomato production. HortScience 47:621-625.

Momol, M., Jones, J., Olson, S., Obradovic, A., Balogh, B., and King, P. 2002. Integrated management of bacterial spot on tomato in Florida. Fact Sheet PP110, Florida Cooperative Extension Service, Institute of Food and Agricultural Sciences, University of Florida.
Musante, C., and White, J. C. 2012. Toxicity of silver and copper to Cucurbita pepo: Differential effects of nano and bulk-size particles. Environ. Toxicol. 27:510-517.

Obradovic, A., Jones, J. B., Momol, M. T., Balogh, B., and Olson, S. M. 2004. Management of tomato bacterial spot in the field by foliar applications of bacteriophages and SAR inducers. Plant Dis. 88:736-740.

Obradovic, A., Jones, J. B., Momol, M. T., Olson, S. M., Jackson, L. E., Balogh, B., Guven, K., and Iriarte, F. B. 2005. Integration of biological control agents and systemic acquired resistance inducers against bacterial spot on tomato. Plant Dis. 89:712-716.

Ocsoy, I., Gulbakan, B., Chen, T., Zhu, G., Chen, Z., Sari, M. M., Peng, L., Xiong, X., Fang, X., and Tan, W. 2013a. DNA-guided metal-nanoparticle formation on graphene oxide surface. Adv. Mater. 25:2319-2325.

Ocsoy, I., Paret, M. L., Ocsoy, M. A., Kunwar, S., Chen, T., You, M., and Tan, W. 2013b. Nanotechnology in plant disease management: DNA-directed silver nanoparticles on graphene oxide as an antibacterial against Xanthomonas perforans. ACS Nano 7:8972-8980.

Pal, S., Tak, Y. K., and Song, J. M. 2007. Does the antibacterial activity of silver nanoparticles depend on the shape of the nanoparticle? A study of the gram-negative bacterium Escherichia coli. Appl. Environ. Microbiol. 73:1712-1720.

Paret, M. L., Sharma, S. K., and Alvarez, A. M. 2012. Characterization of biofumigated Ralstonia solanacearum cells using micro-Raman spectroscopy and electron microscopy. Phytopathology 102:105-113.

Paret, M. L., Vallad, G. E., Averett, D. R., Jones, J. B., and Olson, S. M. 2013. Photocatalysis: Effect of light-activated nanoscale formulations of $\mathrm{TiO}_{2}$ on Xanthomonas perforans and control of bacterial spot of tomato. Phytopathology 103:228-236.

Pérez-de-Luque, A., and Rubiales, D. 2009. Nanotechnology for parasitic plant control. Pest Manage. Sci. 65:540-545.

Pietrzak, U., and McPhail, D. 2004. Copper accumulation, distribution and fractionation in vineyard soils of Victoria, Australia. Geoderma 122:151-166.

Potnis, N., Timilsina, S., Strayer, A., Shantharaj, D., Barak, J. D., Paret, M. L., Vallad, G. E., and Jones, J. B. 2015. Bacterial spot of tomato and pepper: Diverse Xanthomonas species with a wide variety of virulence factors posing a worldwide challenge. Mol. Plant Pathol. 16:907-920.

Ritchie, D., and Dittapongpitch, V. 1991. Copper-and streptomycin-resistant strains and host differentiated races of Xanthomonas campestris pv. vesicatoria in North Carolina. Plant Dis. 75:733-736.

Sawai, J. 2003. Quantitative evaluation of antibacterial activities of metallic oxide powders $(\mathrm{ZnO}, \mathrm{MgO}$ and $\mathrm{CaO})$ by conductimetric assay. J. Microbiol. Methods 54:177-182

Sawai, J., Kojima, H., Igarashi, H., Hashimoto, A., Shoji, S., Sawaki, T., Hakoda, A., Kawada, E., Kokugan, T., and Shimizu, M. 2000. Antibacterial characteristics of magnesium oxide powder. World J. Microbiol. Biotechnol. 16:187-194.

Servin, A., Elmer, W., Mukherjee, A., De la Torre-Roche, R., Hamdi, H., White, J. C., Bindraban, P., and Dimkpa, C. 2015. A review of the use of engineered nanomaterials to suppress plant disease and enhance crop yield. J. Nanopart. Res. 17:92.

Stall, R., and Thayer, P. 1962. Streptomycin resistance of the bacterial spot pathogen and control with streptomycin. Plant Dis. Rep. 46:389-392.

Stilwell, D., and Graetz, T. 2001. Copper, chromium, and arsenic levels in soil near highway traffic sound barriers built using CCA pressure-treated wood. Bull. Environ. Contam. Toxicol. 67:303-308.

Strayer, A., Ocsoy, I., Tan, W., Jones, J., and Paret, M. 2016. Low concentrations of a silver-based nanocomposite to manage bacterial spot of tomato in the greenhouse. Plant Dis. 100:1460-1465.

Thayer, P. L., and Stall, R. E. 1961. A survey of Xanthomonas vesicatoria resistance to streptomycin. Proc. Fla. State Hortic. Soc. 75:163-165.

USDA. 1997. United States standards for grades of fresh tomatoes. United States Department of Agriculture Agricultural Marketing Service. https:// www.ams.usda.gov/sites/default/files/media/Tomato_Standard\%5B1\%5D.pdf

USDA. 2018. Vegetables 2017 Summary. United States Department of Agriculture National Agricultural Statistics Service. http://usda.mannlib.cornell. edu/usda/current/VegeSumm/VegeSumm-02-13-2018.pdf

Vahabi, K., Mansoori, G. A., and Karimi, S. 2011. Biosynthesis of silver nanoparticles by fungus Trichoderma reesei (a route for large-scale production of AgNPs). Insciences J. 1:65-79.

Vallad, G. E., Pernezny, K. L., Balogh, B., Wen, A., Figueiredo, J. F. L., Jones, J. B., Momol, T., Muchovej, R. M., Havranek, N., and Abdallah, N. 2010. Comparison of kasugamycin to traditional bactericides for the management of bacterial spot on tomato. HortScience 45:1834-1840.

Wani, A. H., and Shah, M. A. 2012. A unique and profound effect of $\mathrm{MgO}$ and $\mathrm{ZnO}$ nanoparticles on some plant pathogenic fungi. J. Appl. Pharm. Sci. 2:40-44.

Wightwick, A. M., Mollah, M. R., Partington, D. L., and Allinson, G. 2008. Copper fungicide residues in Australian vineyard soils. J. Agric. Food Chem. 56:2457-2464.

Winge, D. R., and Mehra, R. 1990. Host defenses against copper toxicity. Int. Rev. Exp. Pathol. 31:47-83. 